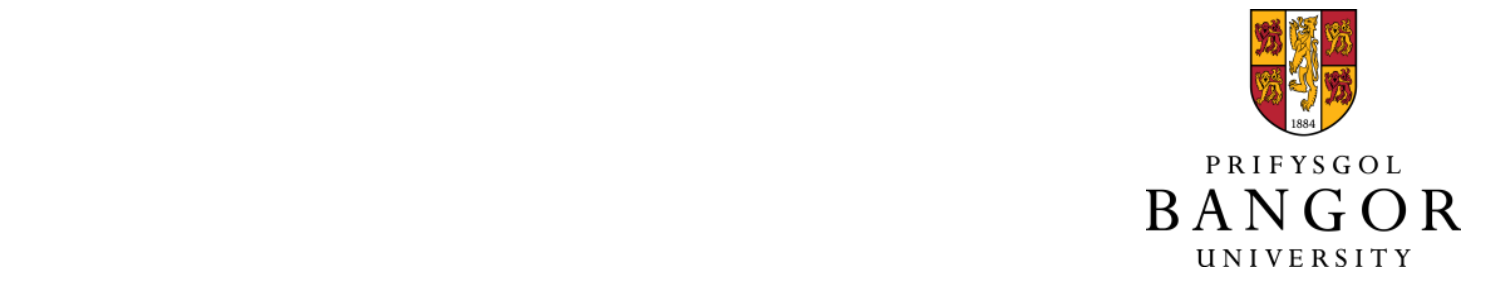

\title{
Prioritization of knowledge-needs to achieve best practices for bottom trawling in relation to seabed habitats
}

Kaiser, Michel J.; Hilborn, Ray; Jennings, Simon; Amaroso, Ricky; Andersen, Michael; Balliet, Kris; Barratt, Eric; Bergstad, Odd A.; Bishop, Stephen; Bostrom, Jodi L.; Boyd, Catherine; Bruce, Eduardo A.; Burden, Merrick; Carey, Chris; Clermont, Jason; Collie, Jeremy S.; Delahunty, Antony; Dixon, Jacqui; Eayrs, Steve; Edwards, Nigel; Fujita, Rod; Gauvin, John; Gleason, Mary; Harris, Brad; He, Pingguo; Hiddink, Jan G.; Hughes, Kathryn M.; Inostroza, Mario; Kenny, Andrew; Kritzer, Jake; Kuntzsch, Volker; Lasta, Mario; Lopez, Ivan; Loveridge, Craig; Lynch, Don; Masters, Jim; Mazor, Tessa; McConnaughey, Robert A.; Moenne, Marcel; Francis; Nimick, Aileen M.; Olsen, Alex; Parker, David; Parma, Ana; Penney, Christine; Pierce, David; Pitcher, Roland; Pol, Michael;

Richardson, Ed; Rijnsdorp, Adriaan D.; Rilatt, Simon; Rodmell, Dale P.; Rose, Craig; Sethi, Suresh A.; Short, Katherine; Suuronen, Petri; Taylor, Erin; Wallace, Scott; Webb, Lisa; Wickham, Eric; Wilding, Sam R.; Wilson, Ashley; Winger, Paul; Sutherland, William J.

\section{Fish and Fisheries}

DOI:

10.1111/faf.12134

Published: 01/09/2016

Peer reviewed version

Cyswllt i'r cyhoeddiad / Link to publication

Dyfyniad o'r fersiwn a gyhoeddwyd / Citation for published version (APA):

Kaiser, M. J., Hilborn, R., Jennings, S., Amaroso, R., Andersen, M., Balliet, K., Barratt, E., Bergstad, O. A., Bishop, S., Bostrom, J. L., Boyd, C., Bruce, E. A., Burden, M., Carey, C., Clermont, J., Collie, J. S., Delahunty, A., Dixon, J., Eayrs, S., ... Sutherland, W. J. (2016). Prioritization of knowledge-needs to achieve best practices for bottom trawling in relation to seabed habitats. Fish and Fisheries, 17(3), 637-663. https://doi.org/10.1111/faf.12134

\footnotetext{
Hawliau Cyffredinol / General rights

Copyright and moral rights for the publications made accessible in the public portal are retained by the authors and/or other copyright owners and it is a condition of accessing publications that users recognise and abide by the legal requirements associated with these rights.

- Users may download and print one copy of any publication from the public portal for the purpose of private study or research.

- You may not further distribute the material or use it for any profit-making activity or commercial gain

- You may freely distribute the URL identifying the publication in the public portal?
} 


\section{Prioritisation of knowledge needs to achieve best practices for bottom- trawling in relation to seabed habitats}

Michel J. Kaiser ${ }^{1}$, Ray Hilborn ${ }^{2}$, Simon Jennings ${ }^{3}$, Ricky Amaroso ${ }^{2}$, Michael Andersen ${ }^{4}$, Kris Balliet ${ }^{5}$, Eric Barratt ${ }^{6}$, Odd A. Bergstad ${ }^{7}$, Stephen Bishop ${ }^{8}$, Jodi L. Bostrom ${ }^{9}$, Catherine Boyd ${ }^{10}$, Eduardo A. Bruce $^{11}$, Merrick Burden ${ }^{12}$, Chris Carey $^{8}$, Jason Clermont ${ }^{13}$, Jeremy S. Collie ${ }^{14}$, Antony Delahunty ${ }^{15}$, Jacqui Dixon ${ }^{16}$, Steve Eayrs ${ }^{17}$, Nigel Edwards ${ }^{18}$, Rod Fujita ${ }^{19}$, John Gauvin ${ }^{20}$, Mary Gleason ${ }^{21}$, Brad Harris $^{22}$, Pingguo He ${ }^{23}$, Jan G. Hiddink ${ }^{1}$, Kathryn M. Hughes ${ }^{1}$, Mario Inostroza ${ }^{24}$, Andrew Kenny ${ }^{3}$, Jake Kritzer ${ }^{25}$, Volker Kuntzsch ${ }^{6}$, Mario Lasta ${ }^{26}$, Ivan Lopez ${ }^{27}$, Craig Loveridge ${ }^{28}$, Don Lynch ${ }^{29}$, Jim Masters $^{30}$, Tessa Mazor ${ }^{31}$, Robert A. McConnaughey ${ }^{32}$, Marcel Moenne ${ }^{33}$, Fancis Neat ${ }^{34}$, Aileen M. Nimick ${ }^{22}$, Alex Olsen ${ }^{35}$, David Parker ${ }^{36}$, Ana Parma ${ }^{37}$, Christine Penney ${ }^{10}$, David Pierce ${ }^{38}$, Roland Pitcher $^{31}$, Michael Pol ${ }^{39}$, Ed Richardson ${ }^{40}$, Adriaan D. Rijnsdorp ${ }^{41}$, Simon Rilatt ${ }^{35}$, Dale P. Rodmell ${ }^{15}$, Craig Rose ${ }^{42}$, Suresh A. Sethi ${ }^{22}$, Katherine Short ${ }^{43}$, Petri Suuronen ${ }^{44}$, Erin Taylor ${ }^{13}$, Scott Wallace ${ }^{45}$, Lisa Webb ${ }^{29}$, Eric Wickham ${ }^{46}$, Sam R. Wilding ${ }^{47}$, Ashley Wilson ${ }^{48}$, Paul Winger ${ }^{49}$ and William J. Sutherland ${ }^{50}$

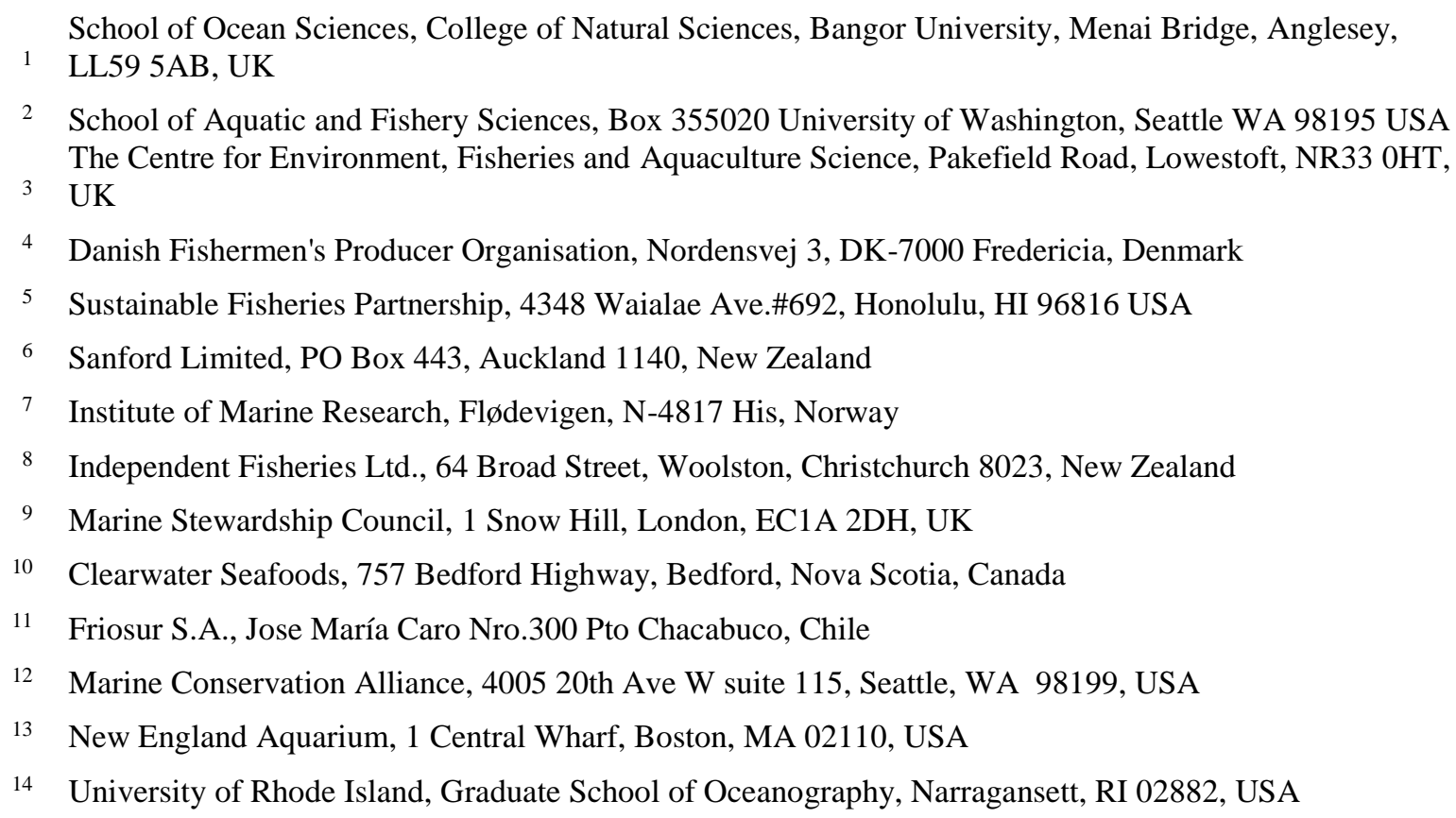


National Federation of Fishermen's Organisations, 30 Monkgate, York, YO31 7PF, UK

Pacific Andes International Holdings Limited, 32/F, Hong Kong Plaza, 188 Connaught Road, West Hong Kong, China

17 Gulf of Maine Research Institute, 350 Commercial St. Portland, ME 04101, USA

Anchorage, AK 99508, USA

Seachill Ltd., La Forey Rd, Great Grimsby Business Park, Grimsby, DN37 9TG, UK

Environmental Defense Fund, 123 Mission Street, 28th Floor, San Francisco, California 94105, USA

Alaska Seafood Cooperative, 4241 21st Ave West, suite 302, Seattle WA 98199, USA

Pacific Street, Suite 200G, Monterey, CA 93940, USA

Fisheries, Aquatic Science \& Technology Laboratory, Alaska Pacific University, 4101 University Dr,

School for Marine Science and Technology, University of Massachusetts Dartmouth, 706 South Rodney French Boulevard, New Bedford, MA 02744 USA

EMDEPES, Avda Providencia 2653, Piso 15. Santiago. Chile.

Environmental Defense Fund, 18 Tremont St, suite 850, Boston, MA 02108, USA

Diag. Montegrande N ${ }^{\circ}$ 7078. B/P Montemar. 7600 Mar del Plata. Argentina

Confederacion Española de Pesca, 7, Doctor Fleming, 2Dcha, 28036, Madrid, Spain

South Pacific Regional Fisheries Management Organisation, PO Box 3797, Wellington 6140, New

Zealand

Gorton's Inc., 128 Rogers St. Gloucester MA, USA

Marine Conservation Society, Over Ross House, Ross Park, Ross-on-Wye, Herefordshire, HR9 7QQ, UK

CSIRO Marine and Atmospheric Research, PO Box 2583, Brisbane, QLD 4001, Australia

US National Marine Fisheries Service, NOAA, 7600 Sand Point Way NE, Seattle, WA 98115, USA.

Pacificblu, Avenida Gran Bretaña 955, Talcahuano, Chile

Marine Scotland Science, Marine Laboratory, 375 Victorial Road, Aberdeen, AB11 9DB, UK.

A. Espersen, Kalvebod Brygge 39-41, DK-1560 Copenhagen, Denmark

Young's Seafood, Ross House, Wickham Road, Grimsby, Lincolnshire DN31 3SW, UK

Centro Nacional Patagonico, CONICET, Puerto Madryn, Argentina

Massachusetts Division of Marine Fisheries, 251 Causeway St. Boston, MA 02114, USA

Massachusetts, Division of Marine Fisheries, 1213 Purchase St - 3rd Floor, New Bedford, MA 02740, USA

Pollock Conservation Cooperative, 4039 21st Avenue West, Suite 400, Seattle, WA USA

Wageningen IMARES, P.O.Box 68, 1970 AB IJmuiden, The Netherlands

FishNext Research, 4707 238th Place SW, Mountlake Terrace, WA 98043, USA

F.L.O.W. Collaborative, 9 Duppa St, Wellington, New Zealand

FAO, Fisheries and Aquaculture Department, Terme di Caracalla, 00153 Rome, Italy

The David Suzuki Foundation, PO Box 19011, West 4th Ave., Vancouver, BC., V6K 4R8, Canada

Unit four --1957 McNicoll Avenue. Vancouver BC V6J 1A7 Canada

Monterey Bay Aquarium, 886 Cannery Row, Monterey, CA 93940, USA

Department for Environment, Food and Rural Affairs, 17 Smith Square, London, SW1P, UK

Memorial University, P.O. Box 4920, St. John's,Newfoundland, A1C 5R3, Canada

Department of Zoology, University of Cambridge, Downing Street, Cambridge, CB2 3EJ, UK 
Correspondence: Michel J. Kaiser, School of Ocean Sciences, Bangor University, Menai Bridge, Anglesey, LL59 5AB, U.K; Email: michel.kaiser@bangor.ac.uk; Tel: + 44 (0)1248 383751 


\begin{abstract}
Management and technical approaches that achieve a sustainable level of fish production while at the same time minimising or limiting the wider ecological effects caused through fishing gear contact with the seabed might be considered to be 'best practice'. To identify future knowledge-needs that would help to support a transition towards the adoption of best practices for trawling a prioritisation exercise was undertaken with a group of 39 practitioners from the seafood industry and management, and 13 research scientists who have an active research interest in bottom-trawl and dredge fisheries. A list of 108 knowledge-needs related to trawl and dredge fisheries was developed in conjunction with an 'expert task force'. The long list was further refined through a three stage process of voting and scoring, including discussions of each knowledge-need. The top 25 knowledge-needs are presented, as scored separately by practitioners and scientists. There was considerable consistency in the priorities identified by these two groups. The top priority knowledge-need to improve current understanding on the distribution and extent of different habitat types also reinforced the concomitant need for the provision and access to data on the spatial and temporal distribution of all forms of towed bottom-fishing activities. Many of the other top 25 knowledge-needs concerned the evaluation of different management approaches or implementation of different fishing practices, particularly those that explore trade-offs between effects of bottom-trawling on biodiversity and ecosystem services and the benefits of fish production as food.
\end{abstract}

Keywords: Habitat impact, knowledge-needs, trawl fisheries, best practices

\title{
Table of contents
}

\author{
Introduction \\ Methods \\ Who was involved? \\ Identification of knowledge- needs \\ Prioritisation of knowledge-needs \\ Data analysis \\ Results \\ Discussion \\ Next steps \\ Acknowledgements \\ Conflicts of interest \\ References \\ Supporting information
}




\section{Introduction}

Approximately sixteen million tonnes of wild captured fish and shellfish are caught annually using bottom trawls and dredges, comprising about twenty percent of global landings (Watson et al., 2006). Bottom trawls and dredges have become the subject of considerable controversy due to their interaction with seabed habitats and their associated fauna. Some claim that any trawl fishery is unsustainable due to its environmental and ecosystem impacts (Watling \& Norse, 1998; Jacquet et al., 2010); leading to calls for bans of some types of trawling (Morton, 2011; Roberts, 2012; Watling, 2013). Trawls and dredges typically use trawl doors, heavy ground ropes, chains or tooth bars to displace, herd and guide fish and shellfish from the seabed into nets. These gear components physically disturb the seabed and its associated flora and fauna (Eigaard et al., in press). The effects of different fishing gears on the seabed vary considerably among gear types and according to the environmental context in which they are fished (reviewed in Stephan et al., 2000; Collie et al., 2000; NRC, 2002; Løkkeborg, 2005; Kaiser et al., 2006; Grabowski et al., 2014). The effects of disturbance from fishing gear can be relatively minor and short-lived in some habitats (e.g. McConnaughy \& Syrjala, 2014, Sciberras et al., 2013, Stokesbury and Harris, 2006), and in others, severe and longlasting, especially in habitats formed by living organisms (e.g. Turner et al., 1999; Beukema, 1995; Hall-Spencer \& Moore, 2000; Koslow et al., 2001; Cook et al., 2013; Clark et al., 2015).

The ecological effects of bottom-fishing with trawls and dredges on non-target benthic invertebrates have been summarized in review papers (Jennings \& Kaiser, 1998; Kaiser et al., 2002; Thrush \& Dayton, 2002) as well as meta-analyses that quantify the relationship between the fishing gear and habitat type and the mortality of benthic invertebrates (Auster, 1998; Collie et al., 2000, Kaiser et al., 2006). These meta-analyses lead to the conclusion that the effects of bottom-trawling on benthic invertebrates may include reductions in biomass, diversity and body size, changes in the functional trait composition of the community (e.g. McConnaughey et al., 2005; Tillin et al., 2005). Furthermore the effects differ greatly between different fishing gears and habitats (Collie et al., 2000; Kaiser et al., 
2006). While the latter studies have informed the degree of impact of bottom trawling under different environmental and biological conditions, there has been a concomitant focus on gear design and deployment to reduce the area of contact or pressure exerted to the seabed (He, 2007; He \& Winger, 2010). Current research has demonstrated that trawl designs can be made lighter or fished in a manner that has less contact area without significantly affecting the catch rate of target species, while presumably reducing the mortality of escaping animals (Rose et al., 2010) or reducing fuel consumption (Suuronen et al., 2012).

The changes in benthic ecosystems that result from the physical contact of bottom-trawl fisheries with the seabed are the focus of an increasing number of legislative initiatives. For example, in the U.S., reauthorization of the Magnuson-Stevens Fishery Conservation and Management Act (Sustainable Fisheries Act, SFA) in October 1996 (Benaka, 1999) mandated fisheries managers to consider the implications of fishing on those habitats upon which the fish depend at key life history stages (Essential Fish Habitat; e.g. Link, 2002). In Europe, the Marine Strategy Framework Directive requires Member States to put in place measures to achieve Good Environmental Status (GES) for marine waters (EU, 2008). The effects of seabed disturbance by trawling is regarded as an impact that may compromise GES (Rice et al., 2010). The New Zealand government with the support of the fishing industry implemented Fisheries (Benthic Protection Areas) Regulations 2007, closing 1.2 million square kilometres of seabed to bottom trawling and dredging (Rieser et al., 2013). Recent amendments to the Chilean Law of Fisheries and Aquaculture have been made for protecting vulnerable and sensitive habitats (implementing protection for 117 seamounts) within it Exclusive Economic Zone from bottom trawling (Hernández-Salas, 2015).

The impacts of bottom trawling on the seabed and the associated mortality of non-target species often concern consumers, especially in wealthy countries, and have thus come to play a central role in consumer-driven information campaigns about product choice. The impact of fishing gear on the seabed is a scoring factor in many sustainable seafood recommendation systems that are aimed at members of the general public and seafood businesses (e.g. Environmental Defense Fund Seafood Selector: www.seafood.edf.org; Monterey Bay Aquarium Seafood Watch: www.seafoodwatch.org; 
World Wildlife Fun Sustainable Seafood Consumer Guides: www.wwf.panda.org). Furthermore the Marine Stewardship Council recently revised its standard such that it now places a much stronger emphasis on the evaluation of the effects of trawl gear on seabed habitats and their associated biota.

Considering the need to maintain the yield from wild capture fisheries to feed an increasing world population, there is a pressing need to evaluate whether trawl and dredge fisheries may impact the productivity of demersal fish species that depend on specific habitats for food and shelter (Auster \& Langton, 1999). For the reasons above, the issue of trawl and dredge impacts on seabed habitats and fauna remains an important policy and management question at a global level. This policy need has continued to stimulate considerable investment in experimental and comparative studies to quantify the effects of different fishing gears in different environmental contexts. As such it is timely to ask the science and practitioner community to identify the key questions in this area that need to be addressed to inform appropriate policy and management.

The concept and process of knowledge exchange is increasingly receiving attention from funding agencies as a means to maximise the impact of public expenditure on research. The identification of knowledge-needs relevant to policymakers and practitioners is itself a research exercise, for which there exists a systematic methodology (Sutherland et al., 2006, 2011). This systematic methodology is tried and tested for a variety of fields of ecology (Table 1) and the strength of this process lies in the implementation of a collaborative, cross-sectoral approach based on 'experiential, theoretical and empirical knowledge' (Nutley et al., 2007; Dicks et al., 2012).

The process and its outputs have had a high impact, specifically in shaping national science policies. For example, in the U.K. Government's Marine Science Strategy research questions across each section were acknowledged as being informed by the 'U.K. 100 ecology questions exercise' (Sutherland et al., 2006). Moreover, the questions identified by Jones et al. (2014) stimulated a £10M investment in aquaculture research by the national research councils while outputs of the prioritisation exercise were also used to frame the structure of the research call. 
Bottom trawling takes place in most of the world's oceans, so the present paper seeks to identify and prioritise global knowledge gaps that, if addressed, would lead to significant advances in the development of best practices for bottom-trawl fisheries (including dredging) globally, such that fisheries production could be maintained (or increased) while minimising adverse impacts on the seabed and its constituent fauna.

\section{Methods}

Hereafter, and unless otherwise stated, we use the phrases 'bottom-trawl fisheries' and 'bottom trawling' to include all towed fishing gears that have physical contact with the seabed; including otter and beam trawls, seines and dredges (this definition could also extend to other fishing activities that directly impact the substratum such as hand raking). To identify and prioritise knowledge-needs necessary to inform the development of best practices for bottom-trawl fisheries, a two-stage process was implemented based on the method of Sutherland et al., (2011) and Dicks et al., (2012). In stage one; knowledge-needs were collaboratively identified by a wide range of stakeholders (Annex 1). In stage two, the resultant list of needs that had been generated was prioritised during two voting sessions followed by a final scoring session. The generation of knowledge-needs and initial voting session were conducted remotely (using on-line voting). The final voting and scoring sessions were conducted at a one-day workshop held in the New England Aquarium, Boston, MA, U.S.A. on the $18^{\text {th }}$ March 2015.

Who was involved?

In total, 52 stakeholders participated in one or more stages of the process and are included as authors of the present study (thus their addresses demonstrate the breadth of the participation). Participants involved in the process were based in 11 different countries (Australia, Argentina, Canada, Chile, China, Denmark, New Zealand, Norway, Spain, U.K., U.S.) and were categorised as either 'research scientists' $(n=13)$ or 'practitioners' $(n=39)$. The practitioners were drawn from the fishing industry (16), processing industry (8), environmental Non-Governmental Organisations (11) and Government 
agencies (3) and one inter-governmental organisation. The term 'research scientist' refers to participants that are actively engaged in research focused on understanding the how trawling interacts with the seabed or engaged in research to mitigate these effects through the use of technical modifications to the fishing gear. In addition to the 52 stakeholders, 12 expert scientists with a range of specialisms (ranging across population and ecological modelling, trawl impact experiments and fishing gear technology) were selected to help the discussion of knowledge-needs throughout the process, these individuals were termed 'the expert task force'. Of this group, only two individuals participated in the final scoring of the priority questions to ensure broader representation from the wider scientist community.

\section{Identification of knowledge-needs}

The process is summarised in a flow diagram (Figure 1). The 64 Participants were asked to consult widely (which drew together the views of a further 56 stakeholders) and then to identify areas where scientific knowledge is most needed (and is currently lacking) to underpin the development of bestpractice. Best-practice was defined as bottom-trawling that would achieve sustainable fisheries production while minimising adverse impacts on the environment (Figure 1). Each participant was requested to submit up to ten specific knowledge-needs that could be answerable through scientific research within a three to five year period. As a guide, participants were provided with example knowledge-needs developed through a comparable exercise that had focused improving the environmental sustainability of aquaculture for the UK food system (Jones et al., 2014). Knowledgeneeds with a similar theme were grouped by MJK and scrutinised by the expert task force. Each

knowledge-need featured on the list just once. Categories of knowledge-needs (Table 2) were identified post-hoc to facilitate the face-to-face process at the final stage of the prioritisation exercise.

\section{Prioritisation of knowledge-needs}

In the first voting stage, participants voted remotely on the long list of knowledge-needs. The original wording of the individual knowledge-needs was retained to avoid misinterpretation of the author's intention and to ensure transparency in the process. Participants were asked to select the $20 \%$ of the 
items listed within each category that represented the most pressing knowledge-needs required to underpin best management practice of bottom-trawl fishing. Participants were invited to make anonymous comments and/or suggest alternative wording for a specific knowledge-need. The knowledge-needs in each category were ranked according to the number of votes that each received. The number of votes that were allocated to each of the questions were visible to participants during the subsequent workshop.

At the workshop, knowledge-needs were discussed during 90-minute sessions dedicated to each of the four categories (Table 2). Four sessions ran in parallel, therefore each participant was involved in three discussion sessions (two separate categories and the final plenary session). Each session had approximately equal numbers of participants and captured a wide range of interests and expertise which is best-practice as recommended by social-psychologists (Hussler et al., 2011; Yaniv, 2011). As the discussion sessions were designed to be practitioner-led, groups contained a maximum of eight research scientists to prevent them dominating the discussion. Group numbers were small enough to encourage discussion, yet large enough to enable a consensus position to be reached. Research scientists were able to provide insight into completed and on-going research surrounding each knowledge-need. Practitioners were asked to identify knowledge-needs that, if met, would lead to their organisations changing policy or practice, with the objective of enhancing the sustainability of their catches or supplies. Each session had a non-voting chairperson to facilitate the discussion process without influencing the decisions.

Knowledge-needs with more votes were allocated more discussion time. Nevertheless, sufficient opportunity was afforded to discuss knowledge-needs with few or no votes as previous experience demonstrates that some of these questions may be promoted after discussion ( for method and rationale see Dicks et al., 2013). At this stage any re-wording or amalgamation of knowledge-needs was established through group consensus. Through discussion, knowledge-needs were eliminated to create a short list within each category. A maximum of $25 \%$ of the original list was retained. A list of 26 knowledge-needs, drawn from across all four category sessions, was generated but not ranked (e.g. Dicks et al., 2013). 
A plenary session was dedicated to the final voting stage and involved all workshop participants. Each of the 26 knowledge-needs was briefly outlined (for the benefit of those who had not been in the relevant sessions). Further rewording of the questions was permitted to improve clarity but only with consensus of the group. Individual participants privately scored each knowledge-need on a scale between 1 and 10, with 10 equal to highest importance. Participants were requested to score across the full range of values. Workshop chairpersons and observers neither voted nor scored the questions at any stage.

\section{Data analysis}

Based on the 108 original knowledge-needs a final list of the top 25 priority knowledge-needs was identified according to median practitioner scores (Table 3). When median practitioner scores were equal across knowledge-needs, ranking was determined by combining both practitioners and research scientist scores, and in the case of continued ties, thereafter ranked according to the lowest interquartile range (least variability amongst scores). While a decision was made to rank the top 25 knowledge-needs according to practitioners' scores in order to emphasize information gaps relevant to stakeholders directly involved in the management and implementation of commercial fisheries, scoring between scientist and practitioner groups was highly consistent (see below).

A Friedman test (Friedman 1940) was used to identify whether any of the top 25 knowledge-needs were scored significantly differently from others. In order to understand to what extent practitioners and scientists agreed or disagreed in their prioritisation of the top 25 knowledge- needs, we used a suite of tests. First, we examined the strength of relationship between median scores for knowledgeneeds for practitioners and median scores for scientists using Spearman rank correlation and simple linear regression. Second, we investigated the pattern of differences in the ranking given to each of the top 25 knowledge-needs between the practitioner and scientist groups using one-way analysis of similarity (ANOSIM) and non-metric multidimensional scaling implemented in PRIMER version 6.1 (Plymouth Routines in Multivariate Ecological Research, Plymouth Marine Laboratory, Plymouth, U.K.; Clarke, 1993; Clarke \& Gorley, 2006). Non-metric multidimensional scaling utilized a 
resemblance matrix calculated with the Bray-Curtis coefficient on untransformed data (Bray \& Curtis, 1957; Field et al., 1982).

\section{Results}

Of the 108 potential knowledge-needs that were split into four categories, 26 were promoted through to the final scoring session (Annex 2; Annex 3; Table 2), of which the 25 top ranked priority knowledge-needs were identified through the scores generated by the participants (i.e. one knowledge need was dropped from the list as it was ranked $26^{\text {th }}$ ) (Table 3). Median scores for practitioners and research scientists are presented separately (Table 3). Knowledge-needs from each of the four categories are represented in the top 10 priority knowledge-needs identified by practitioners (Table 3 ). Interestingly, the knowledge-need 'What is the extent and distribution of different seabed habitat types?' which was the top ranked knowledge-need by both practitioners and scientists achieved only one vote in the original list of 108 knowledge-needs. Significant differences occurred between the scores attributed to the top 25 knowledge-needs (Friedman test, $\chi^{2}=135.2$, d.f. $=24, \mathrm{P}<0.001$ ) which indicated that there was a robust basis on which to prioritize them.

The median scores obtained from practitioners and research scientists were strongly positively correlated for each of the top 25 knowledge-needs from across the themes and hence indicated agreement among practitioners and scientists (Figure 2; Spearman rank correlation $=0.68, \mathrm{P}=0.0003$ ). Simple linear regression indicated that a 95\% confidence interval for the slope between median practitioner scores and median scientists' scores includes 1.0 (Figure 2; slope coefficient $=1.20, \mathrm{SE}=$ $0.28, \mathrm{P}=0.0004,95 \%$ confidence interval $=0.68,1.80)$. Differences between median scores for practitioners and scientists were subtle. The lowest median score for any of the top knowledge-needs for practitioners (range $=6.0,10.0$ ) was larger than the lowest median score for scientists (range $=4.0,10.0)$. The two groups had high agreement (low median score discrepancy) for the topranked and bottom-ranked knowledge-needs, with somewhat more variability in median scores for the middle-ranked knowledge-needs (Figure 3). This variability was typified by two questions in particular; Q16 was scored more highly by scientists and was much more specific, whereas Q64 was 
score more highly by practitioners but dealt with much broader and interacting issues. However despite these individual discrepancies, the analysis of similarity of the scoring given to individual knowledge-needs revealed no significant difference in the scoring patterns amongst knowledge-needs between practitioners and research scientists (ANOSIM, $\mathrm{R}=0.057, \mathrm{P}=0.26$ ). Multivariate analysis revealed that the scientist and practitioner scores did not differ in terms of the scores given within each category of the top 25 knowledge-needs (Figure 4; Ecosystem effects and productivity, ANOSIM, $\mathrm{R}=0.01, \mathrm{P}=0.47$; Direct effects, ANOSIM, $\mathrm{R}=-0.074, \mathrm{P}=0.20$; Operational, ANOSIM, $\mathrm{R}=0.08, \mathrm{P}=0.20$; Management and indicators, $\mathrm{ANOSIM}, \mathrm{R}=0.08, \mathrm{P}=0.20$ ).

\section{Discussion}

The scoring between practitioners and research scientists was remarkably consistent within and between discussion sessions and it was not possible to separate the scores of the two groups statistically. There was sufficient differentiation between the individual knowledge-needs to allow them to be differentiated statistically and hence prioritised. The differentiation between the knowledge-needs is important if the outcome is to be used as a basis for prioritizing research funding or investment in the acquisition of knowledge that would make a significant difference to the environmental performance of fishing or businesses that depend upon fishing.

Both practitioners and research scientists agreed consistently that the top priority knowledge-need was 'Q94 - What is the extent and distribution of different seabed habitat types?' which had a median score of 10 and the lowest inter-quartile range (1.5). This consensus is reassuring given the wide range of stakeholders engaged throughout the process, but underlines the importance of understanding better the overlap between bottom-trawl fishing and different habitat types. The extent and distribution of some marine habitats such as shallow coral reefs and seagrass beds is relatively easily determined using remote sensing technology such as satellite imaging, however for the majority of seabed that occurs in areas with high water turbidity or below the depth of $50 \mathrm{~m}$ our knowledge is limited to direct sampling of the seabed or ad hoc surveys using acoustic technologies (see Kenny et 
al., 2003). Thus any attempt to understand the consequences of bottom-trawling on seabed habitats is likely to be prone to variable amounts of error depending on the quality of the underlying habitat information that is available for the relevant location.

The focus on 'knowledge gathering' to address specific questions is perhaps indicative of a relatively mature area of science for which understanding the key issues are quite well understood. This contrasts with the recent 'aquaculture' prioritisation exercise (Jones et al., 2014) for which a mechanism of knowledge exchange was deemed to be the highest priority knowledge-need. In the case of bottom-trawl fishing there exist already management mechanisms and legal instruments that integrate a consideration of the interaction between bottom-trawling gears and seabed habitats (e.g. the Magnuson-Stevens Fishery Conservation and Management Act (MFCMA) and in Europe the Marine Strategy Framework Directive). Furthermore there have been a number of attempts to develop risk evaluation matrices into which existing empirical information can be fed and the outputs used to advise on management actions (e.g. NRC, 2008; Eno et al., 2013).

All four of the categories of research needs were represented in the top 10 of the top 25 knowledgeneeds. However, the category 'Management and indicators' was most prominent with six knowledgeneeds in the top 10. Of these, the second ranked question (Q53 - What level of trawl fishing impact on other ecosystem services is acceptable such that sustainable seafood production can be maintained?) is interesting in that it seeks to understand the biological threshold of change to ecosystem services that can occur as a result of bottom -trawling without impeding sustainable food production from the sea, but at the same time taking account of the wider societal view of what level of change society is prepared to tolerate. While there exist well established targets for what can be considered sustainable levels of exploitation of harvested species (e.g. a fishing mortality associated with maximum sustainable yield, $\mathrm{F}_{\mathrm{MSY}}$ ) there exist few similar management or conservation targets specifically for wider ecosystem services (Carwardine et al., 2009). Some biodiversity conservation policy initiatives have addressed the latter to some extent, with targets to protect or maintain a proportion of features (e.g. 30\% by area) within networks of marine reserves (Natural England and Joint Nature Conservation Committee, 2010). These are set to meet objectives such as improving or maintaining 
biodiversity (De Santo \& Jones, 2007; Day et al., 2008). A novel example of reference points for benthic fauna has been developed in Canada in relation to coral and sponge bycatch through an agreement between the fishing industry and a coalition of environmental non-governmental organisations (Fisheries and Oceans Canada, 2013). The knowledge-need on acceptable impacts also implies that the biological responses of the stock and the associated changes in ecosystem services that result from bottom-trawling need to be weighed against the social and economic outcomes given different scenarios of bottom-trawling. Information on these trade-offs would be used to inform the debate about what is acceptable.

Knowledge- needs Q44 (rank 3) and Q50 (rank 6) were closely associated with Q53 above. Firstly, as for the top priority question, Q50 addresses the need to understand how much bottom-trawling activity occurs and where this is located. While we have access to vessel monitoring system (VMS) data in many developed countries (e.g. Piet \& Hintzen, 2012) the resolution of these data are often restricted through confidentiality such that it becomes less useful to answer scientific questions such as Q50 (e.g. Hinz et al., 2012). Furthermore these data are usually only available for a selection of vessels (e.g. in Europe all vessels $>12 \mathrm{~m}$ in length) such that there is no information for the more numerous remainder of the fleet. In many developing countries either VMS does not exist or there is limited capacity to process this data. Q44 evolved as an amalgamation of three of the original questions that all sought to evaluate the performance of different management measures using spatial, effort-based or technical measures (fishing gear design, configuration or operation). It is impossible to answer this question without a good understanding of the spatial and temporal distribution of fishing activity (Q50). While spatial management measures may be the only means to protect sessile or site specific conservation features, the displacement of fishing effort into adjacent waters where target species may be less abundant, can lead to negative outcomes depending on the biodiversity conservation or fisheries management objective (Hiddink et al., 2006).

Knowledge-needs Q15 (rank 4), Q6 (rank 5), Q63 (rank 8) and Q83 (rank 13) were all closely related in that they dealt with understanding the recoverability of habitats in relation to trawling, how we evaluate the associated changes in habitat status and how these changes relate to the changes that 
occur in response to natural disturbances. It should be noted that these knowledge-needs are equally relevant in the context of improving performance in relation to biodiversity conservation. Specifically Q15 seeks to understand whether we can use the physical and biological attributes of seabed habitats and the environment in which they occur (i.e. the water column processes overlying them) to infer resilience (and recovery) from bottom-trawl impacts. A large number of empirical studies have demonstrated the wide range of responses of different habitats to different types of fishing gear (reviewed in Kaiser et al., 2006), but only recently have large scale comparative studies started to address the issue of recovery post-fishing at spatial scales that are appropriate (e.g. Sciberras et al., 2013; McConnaughey et al., 2014). Understanding which combination of habitat variables predicts recovery would facilitate the development of broad scale predictive maps of habitat sensitivity that could be used for management purposes (see Hiddink et al., 2007). Linked to this, Q63 seeks to understand to what extent bottom-trawl disturbance differs from, or is similar to, natural perturbations of marine habitats which set the natural background context within which fishing occurs. For example, it is often cited that shallow nearshore areas that are subject to winter storms are more resilient to bottom fishing disturbance (e.g. Kaiser et al., 2002), but the effects of that fishing disturbance may have more profound effects on the habitat if it occurs in the summer c.f. the winter when many benthic biota are senescent (van Denderen et al., 2015). McConnaughey and Syrjala (2014) suggested that the benthic habitat in their Bering Sea study area is affected more by natural storm events than trawl disturbance. If we are to assess change in seabed habitats and their biota in relation to fishing this implies that we understand the status of those habitats prior to the commencement of fishing. Q6 emphasises that at present we have no established reference points against which to evaluate the effects of trawling that could be used to trigger management action, although Holland and Schnier (2006) have suggested the use of 'habitat quotas' as a means of limiting the effects of trawling on the seabed. Extending this idea further (Q83), beyond the initial impact of a single trawl disturbance of the seabed, it is important to understand the additional effects of repeated trawling within the original trawl footprint in a way that is quantifiable (e.g. Hiddink et al., 2006). Indeed, participants cited the continued productivity of trawled areas as a key question among users of bottom-trawl gears when considering habitat impacts. 
In the last decade, there has been considerable research investment in attempting to design fishing gear that have reduced contact with the seabed and by implication reduced impacts on physical and biological attributes of the seabed (e.g. Suuronen et al., 2012). For example, in the North Sea flatfish fisheries, the tickler chain beam trawl gear is being replaced by electrical bottom trawls with a reduced bottom impact and bycatch of benthic invertebrates (van Marlen et al., 2014; Depestele et al., 2015). Six of the knowledge-needs addressed issues that were to some extent related to understanding better the interaction between fishing gear and the seabed or improving catch efficiency in a way that reduces seabed interaction (Q13 rank \#7; Q102 rank \#10; Q16 rank \#11; Q18 rank \#17; Q34 rank \#18; Q12 rank \#20). To date, most evaluations of the effects of fishing gear on benthic communities have made no differentiation between the impact of the different components of the fishing gear (e.g. Collie et al., 2000; Kaiser et al., 2006). However, as there is now greater scrutiny of the effects associated with bottom-trawl fishing and greater capability to assess them, it will become increasingly necessary to understand more precisely which components of fishing gear are responsible for direct contact with the seabed (Q16) (Eigaard et al., in press). The need to identify and to devise mitigation measures through modifications to gear designs and/or operational methods is also identified as a priority (Q102). Indeed some designs and methods are available for adoption in different bottom trawl fisheries with local tests and adaptation (He and Winger 2010; Moran and Stephenson 2010).

Understanding how to measure these interactions and which measurements provide a predictive basis to infer ecological consequences on the seabed is important from a management perspective. For example, in the case of European scallop dredge fisheries, there is a tendency to assume that the tooth bars on the dredge have the largest impact on benthic fauna, whereas the scouring of the steel-ringed belly bag is the element of the gear that has the largest effect on the seabed (Hinz et al., 2012). Q12 recognises the need of managers to have a consistent means of categorising gear in terms of the interaction that each has with the marine environment such that the effects of one gear can be objectively assessed against other options. For that reason, understanding the interaction of different gear components with the seabed is highly relevant (Eigaard et al., in press). 
The lower ranked of the top 25 knowledge-needs (Q32 rank \#21, Q43 rank \#23, Q42 rank \#25) were related to understanding how the spatial configuration of bottom-trawling interacts with seabed habitats at differing landscape scales. At the broadest biogeographic scale, fishing tends to be highly aggregated (e.g. Rijnsdorp et al., 1996; Mangano et al., 2014) and while the small scale $(\sim 3 \mathrm{~km})$ effects of trawl fishing will alter benthic community and habitat structure over different timescales, these effects may be relatively small if accounted for at a larger scale. Furthermore, the configuration of unfished areas of the seabed among and around the sites of trawl fishing may play a critical role in facilitating the recovery of fished areas of the seabed (Lambert et al., 2014) and may facilitate the survivorship of different life-history stages of commercially important species of fish (e.g. Walters \& Juanes, 1993). In some cases bottom-trawling could enhance or replace habitat complexity through the creation of scour pits and ridges (e.g. in mud habitats) that would normally be generated by bioturbating megafauna, however this remains speculation without formal investigation.

Finally, bottom-trawling may impact the productivity (Q30 rank \#12, Q97 rank \#9) of demersal fish species that depend on seabed habitats for food and shelter (Auster\& Langton, 1999). For example, trawling may negatively affect prey availability, potentially leading to reduced food intake, body condition and yield of fishes in chronically trawled areas (Hiddink et al., 2011; Johnson et al., 2014 ; but see van Denderen et al., 2013). Removal of sessile epifauna, like sponges and corals, could also increase exposure of juvenile fish to predators. These indirect effects of trawling through changes in habitat and food availability occur next to the direct removal of target fish biomass that would occur with any fishing gear. For these indirect effects to be important, their negative effects on fish productivity would need to be larger than the effect of the release from competition caused by the reduction in fish stocks. The latter requires evaluation at the appropriate spatial scales if these effects are to be included in appropriate management plans that seek to maximise efficient food production through fisheries while limiting effects of bottom-trawling on the seabed in a proportionate manner. Undertaking a full environmental and efficiency evaluation of fish production using bottom-trawls would be particularly useful in evaluating the potential advantages or disadvantages of alternative approaches to harvesting wild capture species (Q21 rank \#24). 


\section{Next steps}

The knowledge-needs identified through the current exercise are already quite specific and many are additive in that answering one knowledge-need would facilitate progress towards another (e.g. Q94 and Q50 underpin the many of the other knowledge-needs). Future research in this field should continue to draw upon the combined knowledge of producers, processors, retailers and eNGOs, government representatives and research scientists. Continuation of collaborative work across sectors, including iterative discussions, will facilitate ongoing appraisal of the extent to which the priority knowledge-needs identified are being met by emerging knowledge and where knowledge gaps remain.

\section{Acknowledgements}

MJK, RH and SJ were in receipt of research funds from The Walton Foundation and the David and Lucile Packard Foundation and 10 fishing companies that directly supported the work undertaken in this paper. We gratefully acknowledge the help of the New England Aquarium, Boston, MA in hosting the final event and for the editorial support offered by Molly Pugh and Ian Kinahan. WJS was funded by Arcadia. ADR and JGH were supported by the FP7-project BENTHIS (312088). Findings in this article are those of the authors and do not necessarily represent the views of the U.S. Government.

\section{Conflicts of interest}

With the exception of the scientist authors listed, all remaining authors represented the interests of organisations in this process. We do not interpret this as a conflict of interest because the process was 
designed to take account of a wide range of interests, including those of commercial, government and other organisations (Annex 1). 


\section{References}

Auster, P. J. (1998). A conceptual model of the impacts of fishing gear on the integrity of fish habitats. Conservation Biology, 12: 1198-1203.

Auster, P. J., \& Langton, R. W. (1999). The effects of fishing on fish habitat. In American Fisheries Society Symposium (Benaka L.R. ed.) Vol. 22, pp 150-187.

Benaka, L. R. (Ed.) (1999). Fish habitat: essential fish habitat and rehabilitation. American Fisheries Society, Bethesda, Maryland. 400 p.

Beukema, J. J. (1995). Long-term effects of mechanical harvesting of lugworms Arenicola marina on the zoobenthic community of a tidal flat in the Wadden Sea. Netherlands Journal of Sea Research, 33: $219-227$.

Borja, Á., Elliott, M., Carstensen, J., Heiskanen, A. S., \& van de Bund, W. (2010). Marine management-towards an integrated implementation of the European Marine Strategy Framework and the Water Framework Directives. Marine Pollution Bulletin, 60: 2175-2186.

Bray, J.R. \& Curtis, J.T. (1957). An ordination of the upland forest community of southern Wisconsin. Ecological Monographs, 27: 325-349.

Carwardine, J., Klein, C. J., Wilson, K. A., Pressey, R. L. \& Possingham, H. P. (2009). Hitting the target and missing the point: target-based conservation planning in context. Conservation Letters, 2: 4-11. 
Clarke, K.R. and Gorley, R.N. (2006). Primer v6: User manual/Tutorial. Primer-E, Plymouth Marine Laboratory, Plymouth, U.K.

Clark, M. R., Althaus, F., Schlacher, T. A., Williams, A., Bowden, D. A. \& Rowden, A. A. The impacts of deep-sea fisheries on benthic communities: a review. ICES Journal of Marine Science, doi: 10.1093/icesjms/fsv123.

Collie J.S., Hall S.J., Kaiser M.J. \& Poiner I.R. (2000). A quantitative analysis of fishing impacts on shelf-sea benthos. Journal of Animal Ecology, 69: 785-798

Cook, R., Fariñas-Franco, J. M., Gell, F. R., Holt, R. H., Holt, T., Lindenbaum, C., Porter, J.S., \& Sanderson, W. G. (2013). The substantial first impact of bottom fishing on rare biodiversity hotspots: a dilemma for evidence-based conservation. PloS one, 8, e69904.

Day, V., Paxinos, R., Emmett, J., Wright, A., \& Goecker, M. (2008). The Marine Planning Framework for South Australia: A new ecosystem-based zoning policy for marine management. Marine Policy, 32: 535-543.

De Santo, E. M., \& Jones, P. J. (2007). Offshore marine conservation policies in the North East Atlantic: emerging tensions and opportunities. Marine Policy, 31: 336-347.

Dicks, L.V., Abrahams, A., Atkinson, J., Biesmeijer, J., Bourn, N., Brown, C., Brown, M.J.F., Carvell, C., Connolly, C., Cresswell, J.E., Croft, P., Darvill, B., De Zylva, P., Effingham, P., Fountain, M., Goggin, A., Harding, D., Harding, T., Hartfield, C., Heard, M.S., Heathcote, R., Heaver, D., Holland, J., Howe, M., Hughes, B., Huxley, T., Kunin, W.E., Little, J., Mason, C., Memmott, J., Osborne, J., Pankhurst, T., Paxton, R.J., Pocock, M.J.O., Potts, S.G., Power, E.F., Raine, N.E., Ranelagh, E., Roberts, S., Saunders, R., Smith, K., Smith, R.M., Sutton, P., Tilley, 
L.A.N., Tinsley, A., Tonhasca, A., Vanbergen, A.J., Webster, S., Wilson, A. and Sutherland, W.J. (2012). Identifying key knowledge-needs for evidence-based conservation of wild insect pollinators: a collaborative cross-sectoral exercise. Policy, 6: 435- 446.

Dicks, L.V., Bardgett, R.D., Bell, J., Benton, T.G., Booth, A., Bouwman, J., Brown, C., Bruce, A., Burgess, P.J., Butler, S.J., Crute, I., Dixon, F., Drummond, C., Freckleton, R.P., Gill, M., Graham, A., Hails, R.S., Hallett, J., Hart, B., Hillier, J.G., Holland, J.M., Huxley, J.N., Ingram, J.S.I., King, V., MacMillan, T., McGonigle, D.F., McQuaid, C., Nevard, T., Norman, S., Norris, K., Pazderka, C., Poonaji, I., Quinn, C.H., Ramsden, S.J., Sinclair, D., Siriwardena, G.M., Vickery, J.A., Whitmore, A.P., Wolmer, W. and Sutherland, W.J. (2013). What Do We Need to Know to Enhance the Environmental Sustainability of Agricultural Production? A Prioritisation of Knowledge-needs for the UK Food System. Sustainability, 5: 3095-3115.

Depestele, J., A. Ivanović, K. Degrendele, M. Esmaeili, H. Polet, M. Roche, K. Summerbell, L. R. Teal, B. Vanelslander \& O'Neill, F. G. (in press). "Measuring and assessing the physical impact of beam trawling." ICES Journal of Marine Science.

Eigaard ,O.R., Bastardie, F., Breen, M., Dinesen, G.E., Hintzen, N.T., Laffargue, P., Nielsen ,J.R., Nilson H., O’Neill, F., Polet, H,, Reid, D.G., Sala, A., Sköld, M., Smith, C., Sørensen, T.K., Tully, O., Zengin, M., \& Rijnsdorp, A.D. (in press) Estimating seafloor pressure from trawls and dredges based on gear design and dimensions. ICES Journal of Marine Science.

Eno, N. C., Frid, C. L. J., Hall, K., Ramsay, K., Sharp, R. A. M., Brazier, D. P., \& Robinson, L. A. (2013). Assessing the sensitivity of habitats to fishing: from seabed maps to sensitivity mapsa. Journal of Fish Biology, 83: 826-846. 
EU (2008) Directive 2008/56/EC of the European Parliament and of the Council of 17 June 2008 establishing a framework for community action in the field of marine environmental policy (Marine Strategy Framework Directive). Official Journal of the European Union, L164: 19-40.

Marlen, van B., Wiegerinck, J. A. M., Os-Koomen, van E., \& Van Barneveld, E. (2014). Catch comparison of pulse trawls and a tickler chain beam trawl. Fisheries Research, 151: 57-69.

Gerritsen, H. D., Minto, C., \& Lordan, C. (2013). How much of the seabed is impacted by mobile fishing gear? Absolute estimates from Vessel Monitoring System (VMS) point data. ICES Journal of Marine Science, 70: 523-531

Lee, J., South, A. B., \& Jennings, S. (2010). Developing reliable, repeatable, and accessible methods to provide high-resolution estimates of fishing-effort distributions from vessel monitoring system (VMS) data. ICES Journal of Marine Science, 67: 1260-1271

Field, J.G. Clarke, K.R. \& Warwick, R.M. (1982). A practical strategy for analysing multispecies distribution patterns. Marine Ecology Progress Series, 8: 37-52.

Fisheries and Oceans Canada. 2013. Pacific Region Integrated Fisheries Management Plan, Groundfish. Version 1.1, 63 pages.

Friedman, M (1940). A comparison of alternative tests of significance for the problem of $m$ rankings. The Annals of Mathematical Statistics 11: 86-92.

Grabowski, J. H., Bachman, M., Demarest, C., Eayrs, S., Harris, B. P., Malkoski, V., Packer, D., et al. (2014). Assessing the vulnerability of marine benthos to fishing gear impacts. Reviews in Fisheries Science \& Aquaculture, 22: 142-155. 
Grieve, C., Brady, D.C. \& Polet, H. (2014). Best practices for managing, measuring and mitigating the benthic impacts of fishing - Part 1. Marine Stewardship Council Science Series 2: $18-88$.

Hall-Spencer, J. M., \& Moore, P. G. (2000). Scallop dredging has profound, long-term impacts on maerl habitats. ICES Journal of Marine Science, 57: 1407-1415.

He, P., \& Winger, P. D. (2010). Effect of trawling on the seabed and mitigation measures to reduce impact. In: Behavior of Marine Fishes: Capture Processes and Conservation Challenges, pages 295314.

He, P. (2007). Technical measures to reduce seabed impact of mobile fishing gears. In: By-catch Reduction in the World's Fisheries (pp. 141-179). Springer Netherlands.

Hernández-Salas, C. R. (2015). Seamounts Protection in the Pacific Insular Region of Chile. Chinese Journal of International Law, doi: 10.1093/chinesejil/jmu046

Hinz H., Murray L.G., Lambert G.I., Hiddink J.G. \& Kaiser M.J. (2012). Confidentiality over fishing effort data threatens science and management progress. Fish and Fisheries, 14: 110-117

Hiddink, J. G., Johnson, A. F., Kingham, R., \& Hinz, H. (2011). Could our fisheries be more productive? Indirect negative effects of bottom trawl fisheries on fish condition. Journal of Applied Ecology, 48: 1441-1449.

Hiddink J.G., Jennings S. \& Kaiser M.J. (2007). Assessing and predicting the relative ecological impacts of disturbance on habitats with different sensitivities. Journal of Applied Ecology, 44: 405413. 
Hiddink J.G., Jennings S., Kaiser M.J., Queirós A.M., Duplisea D.E. \& Piet G.J. (2006). Cumulative impacts of seabed trawl disturbance on benthic biomass, production and species richness in different habitats. Canadian Journal of Fisheries and Aquatic Sciences, 63: 721-736.

Holland, D. S., \& Schnier, K. E. (2006). Protecting marine biodiversity: a comparison of individual habitat quotas and marine protected areas. Canadian Journal of Fisheries and Aquatic Sciences, 63: 1481-1495.

Hintzen, N. T., Bastardie, F., Beare, D., Piet, G. J., Ulrich, C., Deporte, N., Egekvist, J., et al. (2012). VMStools: Open-source software for the processing, analysis and visualisation of fisheries logbook and VMS data. Fisheries Research, 115: 31-43

Hussler, C. Muller, P. \& Ronde, P. (2011). Is diversity in Delphi panellist groups useful? Evidence from a French forecasting exercise on the future of nuclear energy. Technological Forecasting and Social Change, 78: 1642-1653.

Jacquet, J., Pauly, D., Ainley, D., Holt, S., Dayton, P., \& Jackson, J. (2010). Seafood stewardship in crisis. Nature, 467: 28-29.

Johnson, A. F., Gorelli, G., Jenkins, S. R., Hiddink, J. G., \& Hinz, H. (2015). Effects of bottom trawling on fish foraging and feeding. Proceedings of the Royal Society B: Biological Sciences, 282: 20142336

Ingram, John S. I., Wright, H.L., Foster, L., Aldred, T., Barling, D., Benton, T.G., Berryman, P.M., Bestwick, C.S., Bows-Larkin, A., Brocklehurst, T.F., Buttriss, J., Casey, J., Collins, H., Crossley, D.S., Dolan, C.S., Dowler, E., Edwards, R., Finney, K.J., Fitzpatrick, J.L., Fowler, M., Garrett, D.A., Godfrey, J.E., Godley, A., Griffiths, W., Houlston, E.J., Kaiser, M.J., Kennard, R., Knox, J.W., Kuyk, A., Linter, B.R., Macdiarmid, J.I., Martindale, W., Mathers, J.C., McGonigle, D.F., Mead, A., Millar, 
S.J., Miller, A., Murray, C., Norton, I.T., Parry, S., Pollicino, M., Quested, T.E., Tassou, S., Terry, L.A., Tiffin, R., van de Graaf, P., Vorley, W., Westby, A. \& Sutherland,W.J. (2013). Priority research questions for the UK food system. Food Security, 5: 617-636.

Jennings S. \& Kaiser M.J. 1998. The effects of fishing on marine ecosystems. Advances in Marine Biology 34: 201-352.

Jones A.C., Mead A., Kaiser M.J., Austen M.C.V., Adrian A.W., Auchterlonie N.A., Black K.D., Blow L.R., Bury C., Brown J.H., Burnell G.A., Connolly E., Dingwall A., Derrick S., Eno N.C., Gautier D.J.H., Green K.A., Gubbins M., Hart P.R., Holmyard J.M., Immink A.J., Jarrad D.J., Katoh E., Langley J.C.R., Lee D. O’C., LeVay L., Leftwich C.P., Mitchell M., Moore A., Murray A.G., McLaren E.M.R., Norbury H., Parker D., Parry S.O., Purchase D., Rahman A., Sanver F., Siggs M., Simpson S.D., Slaski R.J., Smith K., Syvret M. LeQ., Tibbot C., Thomas P.C., Turnbull J., Whiteley R., Whittles M., Wilcockson M.J., Wilson J., Dicks L.V., \& Sutherland W.J. (in press) Prioritisation of knowledge-needs for sustainable aquaculture: a national and global perspective. Fish and Fisheries, in press

Kaiser M.J., Clarke K.R., Hinz H., Austen M.C.V., Somerfield P.J., \& Karakassis I. (2006). Global analysis and prediction of the response of benthic biota and habitats to fishing. Marine Ecology Progress Series, 311: 1-14

Kaiser M.J., Collie J.S., Hall S.J., Jennings S. \& Poiner I.R. (2002). Modification of marine habitats by trawling activities: prognosis and solutions. Fish and Fisheries, 3: 114-136.

Kenny, A. J., Cato, I., Desprez, M., Fader, G., Schüttenhelm, R. T. E., \& Side, J. (2003). An overview of seabed-mapping technologies in the context of marine habitat classification. ICES Journal of Marine Science, 60, 411-418. 
Koslow, J. A., Gowlette-Holmes, K., Lowret, J. K. et al. (2001). Seamount benthic macrofauna off southern Tasmania: community structure and impacts of trawling, Marine Ecology Progress Series, $213,111-125$

Lambert G.I., Jennings S., Kaiser M.J., Davies T.W. \& Hiddink J.G. (2014). Quantifying recovery rates and resilience of seabed habitats impacted by bottom fishing. Journal of Applied Ecology, 51: 1326-1336.

Link, J. S. (2002). What does ecosystem-based fisheries management mean. Fisheries, 27: 18-21.

Løkkeborg, S. (2005) Impacts of trawling and scallop dredging on benthic habitats and communities. FAO Fisheries Technical Paper 472, 59 p.

Mangano A.C., Kaiser M.J., Porporato E. \& Spano N. (2013). Evidence of trawl disturbance on mega-epibenthic communities in the Southern Tyrrhenian Sea. Marine Ecology Progress Series, 475: $101-117$

McNie, E. (2007) Reconciling the supply of scientific information with user demands: and analysis of the problem and review of the literature. Environmental Science \& Policy, 10: 17-38.

McConnaughey, R.A. \& Syrjala, S.E. (2014). Short-term effects of bottom trawling and a storm event on soft-bottom benthos in the eastern Bering Sea. ICES Journal of Marine Science, 71: 2469-2483.

McConnaughey, R. A., Syrjala, S. E., \& Dew, C. B. (2005). Effects of chronic bottom trawling on the size structure of soft-bottom benthic invertebrates. In: Benthic Habitats and the Effects of Fishing: Proceedings of Symposium on Effects of Fishing Activities on Benthic Habitats: Linking Geology, Biology, Socioeconomics, and Management. P. W. Barnes, and J. P. Thomas (Eds), American 
Fisheries Society Symposium 41, pp. 425-437. American Fisheries Society, Bethesda, Maryland (USA).

Moran, M. J., \& Stephenson, P. C. (2000). Effects of otter trawling on macrobenthos and management of demersal scalefish fisheries on the continental shelf of north-western Australia. ICES Journal of Marine Science, 57: 510-516.

Morton, B. (2011). At last, a trawling ban for Hong Kong's inshore waters. Marine Pollution Bulletin, 62: $1153-1154$.

National Research Council. (2002) Effects of Trawling and Dredging on Seafloor Habitat. National Academy Press, Washington, D.C., USA.

Natural England \& Joint Nature Conservation Committee (2010). MCZ project ecological network guidance. Natural England, Peterborough, U.K. pp144.

Nutley, S.M. Walter, I. \& Davies, H.T.O. (2007). Using Evidence: How research can inform public services. The Policy Press, Bristol, UK.

Piet, G. J., \& Hintzen, N. T. (2012) Indicators of fishing pressure and seafloor integrity. ICES Journal of Marine Science, 69: 1850-1858.

Pretty, J., Sutherland, W.J., Ashby, J. Auburn, J., Baulcombe, D., Bell, M., Bentley, J., Bickersteth, S., Brown, K., Burke, J., Campbell, H., Chen, K., Crowley, E., Crute, I., Dobbelaere, D., EdwardsJones, G., Funes- Monzote, F., Godfray, C.J., Griffon, M., Gypmantisiri, P., Haddad, L., Halavatau, S., Herren, H., Holderness, M., Izac, A.M., Jones, M., Koohafkan, P., Lal, R., Lang, T., McNeely, J., Mueller, A., Nisbett, N., Noble, A., Pingali, P., Pinto, Y., Rabbinge, R., Ravindranath, N.H., Rola, A., 
Roling, N., Sage, C., Settle, W., Sha, J.M., Shiming, L., Simons, T., Smith, P., Strzepeck, K., Swaine, H., Terry, E., Tomich, P., Toulmin, C., Trigo, E., Twomlow, S., Vis, J.K., Wilson, J. and Pilgrim, S. (2010). The top 100 questions of importance to the future of global agriculture. International Journal of Agricultural Sustainability, 8: 219-236.

Rice, J., Arvanitidis, C., Borja, A., Frid, C.L.J., Hiddink, J.G., Krause, J., Lorance, P., Ragnarsson, S.A., Skold, M., \& Trabucco, B. (2010). Marine Strategy Framework Directive - Task Group 6 Report Seafloor integrity. ICES-Joint Research Centre, 73 pp.

Rieser, A., Watling, L. \& Guinotte, J. (2013). Trawl fisheries, catch shares and the protection of benthic marine ecosystems: Has ownership generated incentives for seafloor stewardship? Marine Policy, 40: 75-83.

Rijnsdorp, A. D., Buys, A. M., Storbeck, F., \& Visser, E. G. (1998). Micro-scale distribution of beam trawl effort in the southern North Sea between 1993 and 1996 in relation to the trawling frequency of the sea bed and the impact on benthic organisms. ICES Journal of Marine Science, 55 : 403-419.

Roberts, C. (2012). Ocean of Life: How our Seas are Changing. Penguin, London.

Rose, C. S., Gauvin, J. R., \& Hammond, C. F. (2010). Effective herding of flatfish by cables with minimal seafloor contact. Fishery Bulletin, 108(2), 136-144.

Sciberras M., Hinz H., Bennell J., Jenkins S.R., Hawkins S.J. \& Kaiser M.J. (2013). Community effects of scallop dredging closed area in a dynamic seabed habitat. Marine Ecology Progress Series, 480: 83-98. 
Stephan, C.D., Peuser, R.L., \& Fonseca, M.S. (2000). Evaluating Fishing Gear Impacts to Submerged Aquatic Vegetation and Determining Mitigation strategies, ASMFC Habitat Management Series No.5. Washington, D.C., USA. 38 pp.

Stokesbury, K. D., \& Harris, B. P. (2006). Impact of limited short-term sea scallop fishery on epibenthic community of Georges Bank closed areas. Marine Ecology Progress Series, 307, 85-100. Suuronen, P., Chopin, F., Glass, C., Løkkeborg, S., Matsushita, Y., Queirolo, D., \& Rihan, D. (2012). Low impact and fuel efficient fishing — looking beyond the horizon. Fisheries Research, 119: 135146.

Sutherland, W. J., Armstrong-Brown, S., Armsworth, P. R., Tom, B., Brickland, J., Campbell, C. D., Chamberlain, D. E., Cooke, A. I., Dulvy, N. K., Dusic, N. R., Fitton, M., Freckleton, R. P., Godfray, H. C. J., Grout, N., Harvey, H. J., Hedley, C., Hopkins, J. J., Kift, N. B., Kirby, J., Kunin, W. E., Macdonald, D. W., Marker, B., Naura, M., Neale, A. R., Oliver, T., Osborn, D., Pullin, A. S., Shardlow, M. E. A., Showler, D. A., Smith, P. L., Smithers, R. J., Solandt, J.L., Spencer, J., Spray, C. J., Thomas, C. D., Thompson, J., Webb, S. E., Yalden, D. W. and Watkinson, A. R. (2006). The identification of 100 ecological questions of high policy relevance in the UK. Journal of Applied Ecology, 43: 617-627.

Sutherland, W. J., Armstrong-Brown, S., Armsworth, P. R., Tom, B., Brickland, J., Campbell, C. D., Chamberlain, D. E., Cooke, A. I., Dulvy, N. K., Dusic, N. R., Fitton, M., Freckleton, R. P., Godfray, H. C. J., Grout, N., Harvey, H. J., Hedley, C., Hopkins, J. J., Kift, N. B., Kirby, J., Kunin, W. E., Macdonald, D. W., Marker, B., Naura, M., Neale, A. R., Oliver, T., Osborn, D., Pullin, A. S., Shardlow, M. E. A., Showler, D. A., Smith, P. L., Smithers, R. J., Solandt, J.L., Spencer, J., Spray, C. J., Thomas, C. D., Thompson, J., Webb, S. E., Yalden, D. W. and Watkinson, A. R. (2011). Methods for collaboratively identifying research priorities and emerging issues in science and policy. Methods in Ecology and Evolution, 2: 238-247. 
Sutherland, W.J., Goulden, C., Bell, K., Bennett, F., Burrall, S., Bush, M., Callan, S., Catcheside, K., Corner, J., D’Arcy, C.T., Dickson, M., Dolan, J.A., Doubleday, R., Eckley, B.J., Foreman, E.T., Foster, R., Gilhooly, L., Gray, A-M., Hall, A.C., Harmer, M., Hastings, A., Johnes, C., Johnstone, M., Kelly, P., Kenway, P., Lee, N., Moore, R., Ouchikh, J., Plunkett, J., Rowlingson, K., Scott Paul, A., Sefton, T.A.J., Shaheen, F., Sodha, S., Stearn, J., Stewart, K., Stone, E., Tinsley, M., Tomsett, R.J., Tyrer, P., Unwin, J., Wall, D.G., Wollner, P.K.A. (2013). 100 Questions: identifying research priorities for poverty prevention and reduction. Journal of Poverty and Social Justice, 21: 189-205.

Thrush, S. F., \& Dayton, P. K. (2002). Disturbance to marine benthic habitats by trawling and dredging: implications for marine biodiversity. Annual Review of Ecology and Systematics, 449-473.

Tillin H.M., Hiddink J.G., Jennings S. \& Kaiser M.J. (2006). Chronic bottom trawling alters the functional composition of benthic invertebrate communities on a sea basin scale. Marine Ecology Progress Series 318: 31-45.

Turner, S. J., Thrush, S. F., Hewitt, J. E., Cummings, V. J., \& Funnell, G. (1999). Fishing impacts and the degradation or loss of habitat structure. Fisheries Management and Ecology, 6: 401-420.

Van Denderen PD, Hintzen NT, van Kooten T, Rijnsdorp AD. 2015. The temporal distribution of bottom trawling and its implication for the impact on the benthic ecosystem. ICES Journal of Marine Science, 72: 952-961.

Van Denderen, P. D., van Kooten, T., \& Rijnsdorp, A. D. (2013). When does fishing lead to more fish? Community consequences of bottom trawl fisheries in demersal food webs. Proceedings of the Royal Society B: Biological Sciences, 280: 20131883. 
Van Marlen, B., Wiegerinck, J. A. M., van Os-Koomen, E., \& van Barneveld, E. (2014). Catch comparison of flatfish pulse trawls and a tickler chain beam trawl. Fisheries Research, 151: 57-69.

Watling, L. (2013) Deep-sea trawling must be banned. Nature, 501: 7.

Watling, L., \& Norse, E. A. 1998. Disturbance of the seabed by mobile fishing gear: a comparison to forest clearcutting. Conservation Biology, 12: 1180-1197.

Watson, R., Revenga, C., \& Kura, Y. (2006). Fishing gear associated with global marine catches: II. Trends in trawling and dredging. Fisheries Research, 79: 103-111.

Yaniv, I. (2011). Group diversity and decision quality: amplification and attenuation of the framing effect. International Journal of Forecasting, 27: 41-49. 
Table 1. Natural science topics for which the prioritisation of research knowledge-needs has been undertaken.

\begin{tabular}{|l|l|}
\hline Ecology & Sutherland et al., 2006 \\
\hline Agriculture & Pretty et al., 2010 \\
\hline Conservation of wild insect pollinators & Dicks et al., 2012 \\
\hline UK food security & Ingrams et al., 2013 \\
\hline Poverty alleviation & Sutherland et al., 2013 \\
\hline Aquaculture & \\
\hline
\end{tabular}


Table 2: Content of the four knowledge-need categories necessary to inform the development of best practices for bottom-trawl fisheries.

\begin{tabular}{lll}
\hline Category & Key & Description of proposed knowledge-needs
\end{tabular}

Direct effects

Ecosystem and production

Operational

Management and indicators
D Direct physical effects on either the geological or biological features of the seabed habitat.

$\mathrm{E}$ Wider ecosystem effects of disturbance of the seabed that occurs as a result of bottom-trawling, consequences for fisheries production.

O Alteration to the design of existing fishing gear, or use of alternative fishing gears, or changes to the mechanism of fishing that alleviate contact with the seabed.

M Evaluation of the efficacy of different approaches or applications of knowledge to mitigate the effects of fishing on the seabed, examination of trade-offs between production of fish as food and the consequences of bottom-trawling, indicators of seabed habitat and faunal status in relation to bottom-trawling and natural disturbance. 
Table 3: Top 25 priority knowledge-needs necessary to inform the development of best practices for bottomtrawl fisheries. The knowledge-needs are ranked by median practitioner score (P_MD; 1= low priority, 10= high priority). When practitioner scores were equal, knowledge-needs were ranked according to overall medians (both practitioner and scientist median scores (T_MD)) then according to lowest inter-quartile range (IR). Scientist median scores are given separately (S_MD). Category codes are explained in Table 2. The original question number is shown in the left-hand column.

\begin{tabular}{|c|c|c|c|c|c|c|}
\hline Rank & Number & Knowledge-needs & Category & P_MD & S_MD & T_MD \\
\hline 1 & 94 & What is the extent and distribution of different seabed habitat types? & M & 10 & 10 & 10 \\
\hline 2 & 53 & $\begin{array}{l}\text { What level of trawl fishing impact on other ecosystem services is } \\
\text { acceptable such that sustainable seafood production can be maintained? }\end{array}$ & M & 9 & 8 & 9 \\
\hline 3 & 44 & $\begin{array}{l}\text { What are the relative benefits of spatial management to constrain the } \\
\text { trawl fleet footprint versus trawl effort and technical (gear modification) } \\
\text { controls, and how can we evaluate the outcomes of using different } \\
\text { combinations of these management measures? }\end{array}$ & M & 8 & 8 & 8 \\
\hline 4 & 15 & $\begin{array}{l}\text { What are the habitat-related variables (e.g., biota, substratum type, } \\
\text { current flow, etc) that determine resilience (recovery time) to } \\
\text { disturbance from different types of trawling and in different benthic } \\
\text { habitats? }\end{array}$ & $\mathrm{E}$ & 8 & 8 & 8 \\
\hline 5 & 6 & $\begin{array}{l}\text { What are the reference points and indicators of habitat status that are } \\
\text { needed to assess the sustainability of trawling within any particular } \\
\text { habitat, and can we define the thresholds beyond which habitat change } \\
\text { is irreversible? }\end{array}$ & $M$ & 8 & 8 & 8 \\
\hline 6 & 50 & $\begin{array}{l}\text { What is the spatial and temporal extent and variation in the intensity of } \\
\text { bottom-trawling activity for all vessels? }\end{array}$ & $M$ & 8 & 9 & 8 \\
\hline 7 & 13 & $\begin{array}{l}\text { What kind of information do we need to quantify about seabed habitats, } \\
\text { and about the mode of operation, prevailing environmental conditions } \\
\text { and attributes of fishing gear to understand their interaction? }\end{array}$ & $\mathrm{D}$ & 8 & 9 & 8 \\
\hline 8 & 63 & $\begin{array}{l}\text { How does the disturbance by towed gear and subsequent recovery rate } \\
\text { of habitats and biological communities differ from the frequency, timing, } \\
\text { and magnitude of natural perturbations experienced by seabed habitats? }\end{array}$ & $E$ & 8 & 8 & 8 \\
\hline 9 & 97 & $\begin{array}{l}\text { What is the functional relationship between the biological and physical } \\
\text { attributes of the seabed and the survival and reproduction of managed } \\
\text { stocks? }\end{array}$ & $\mathrm{E}$ & 8 & 9 & 8 \\
\hline 10 & 102 & $\begin{array}{l}\text { What gear configurations (e.g. semi-pelagic) exist to mitigate habitat } \\
\text { impacts and how can these benefits be quantified (e.g. through } \\
\text { numerical models, physical models in a flume tank, or use of technology } \\
\text { or direct observation)? }\end{array}$ & 0 & 7.5 & 9 & 8 \\
\hline 11 & 16 & $\begin{array}{l}\text { What role does the entire fishing gear and its individual components, } \\
\text { such as the doors, sweeps/bridles and footrope, play in the disturbance } \\
\text { of different habitat types? }\end{array}$ & $\mathrm{D}$ & 7.5 & 10 & 8 \\
\hline 12 & 30 & $\begin{array}{l}\text { Does the management of the effects of trawling on the seafloor result in } \\
\text { a change in the productivity of managed stocks? }\end{array}$ & $\mathrm{E}$ & 7.5 & 6 & 7 \\
\hline 13 & 83 & $\begin{array}{l}\text { Within areas that have a history of being trawled, what ongoing } \\
\text { ecosystem changes occur by continuing to trawl within the trawl } \\
\text { footprint? }\end{array}$ & $E$ & 7.5 & 7 & 7 \\
\hline 14 & 100 & $\begin{array}{l}\text { How do we evaluate risks and the opportunities associated with trawling } \\
\text { in areas that presently are not trawled? }\end{array}$ & $M$ & 7.5 & 5 & 7 \\
\hline
\end{tabular}


How do different types of benthic structure-forming biota differ in their susceptibility to impacts from towed gear and their ability to recover after such impacts?

How can we enhance the knowledge obtained from past comparisons between trawled, previously trawled and untrawled areas to extract more specific information on the magnitude of trawl-induced change?

How can knowledge of fish distribution and behaviour, such as gregation and flight response, be better used to increase efficiency and/or reduce bottom time for bottom-trawl gear?

How can we identify an optimal seabed clearance range to achieve both efficient fish capture and avoid seabed impacts?

To what extent are the impacts of towed fishing gear mediated by variation in habitat susceptibility, in species recovery rates and in spatial overlaps between distribution of fishing effort intensity and the distribution of habitats?

What types of attributes and gear characteristics can be used to provide a consistent and systematic way of ranking or measuring the relative impact of different fishing gears across the same range of different habitats?

To what extent does the spatial and temporal pattern of trawling, and variable impacts within trawl tracks, create a pattern of effective refuges within fished areas and how does this vary by fishery and fishing intensity?

In the absence of specific survey data, to what extent can the distributions of species and habitats vulnerable to trawling be predicted with sufficient reliability to enable successful assessments and management responses?

What are the wider seascape scale ecological consequences of the interaction between the spatial arrangement of habitat and trawling?

What are the economic costs and total environmental impacts per unit value of fish caught, and how does this compare to other gears and practices?

What influence do scour marks and topographic changes from trawl gear components have on benthic community structure?
D

7

7

$$
\text { D }
$$

5

7

$\mathrm{O}$

$\begin{array}{lll}7 & 6 & 7\end{array}$

$\begin{array}{llll}0 & 7 & 5 & 6\end{array}$

$\begin{array}{llll}\text { D } & 7 & 4 & 6\end{array}$

$\begin{array}{lll}6.5 & 6 & 6\end{array}$

D

$6.5 \quad 6 \quad 6$

$\begin{array}{llll}M & 6.5 & 6 & 6\end{array}$

$\begin{array}{llll}\text { E } & 6 & 6 & 6\end{array}$

$\begin{array}{llll}0 & 6 & 7 & 6\end{array}$

E 6 
Invitation to identify up to 10 knowledge needs

Expert steering group (12 scientific experts)

Wider science and practitioner community

2

Arrange knowledge needs into themes

Participants allocate defined number of votes to top knowledge needs in each theme

4

Distribute ranked (based on the sum of votes) list of knowledge needs within each theme

5

Face to face meeting to prioritise knowledge needs, refine questions, compile final priority list

Compile top 25 needs across 4 themes, final plenary discussion and scoring

Figure 1: Schematic flow diagram to illustrate the different stages in the prioritisation process as described in the methodology. 


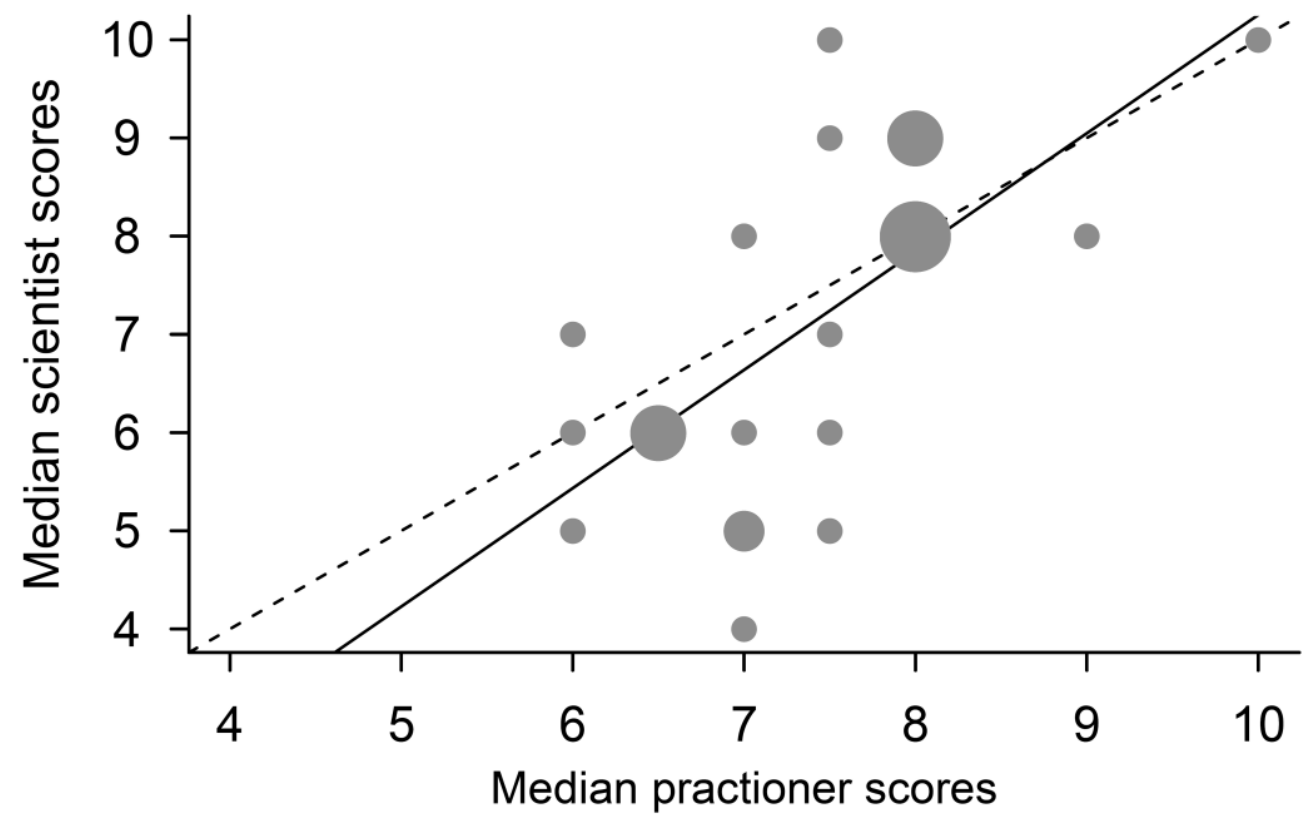

Figure 2. Median scores ( $1=$ low priority, $10=$ high priority) for each of the 25 knowledge needs given by practitioners $(n=39)$ and scientists $(n=13)$. Points are sized according to the number of knowledge needs within each combination of scores (largest circle $=4$ knowledge needs, smallest circle $=1$ ). The dashed line is a 1:1 line; the solid line is a simple linear regression best fit line (slope coefficient $=$ $1.20, \mathrm{SE}=0.28, \mathrm{P}=0.0004,95 \%$ confidence interval $=0.68,1.80$ ). Spearman rank correlation between practitioner median scores and scientist median scores $=0.68(\mathrm{P}=0.0003)$. 


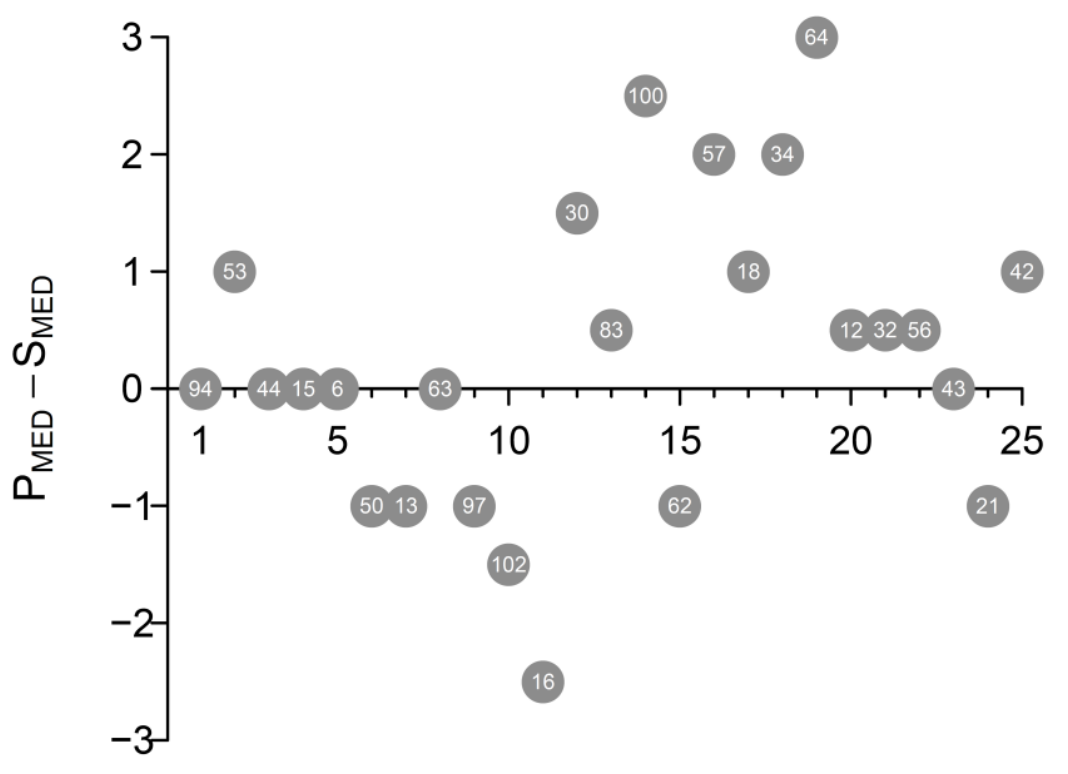

Rankings of top 25 knowledge needs ( 1 = top ranked)

Figure 3. Differences in the median scores (practitioner - scientist) for each of the top 25 knowledge needs given by practitioners $(n=39)$ and scientists $(n=13)$. Questions are plotted in rank order and point labels correspond to question numbers in Table 3. Spearman rank correlation between difference in median scores and knowledge need rank number $=0.32(\mathrm{P}=0.114)$. 


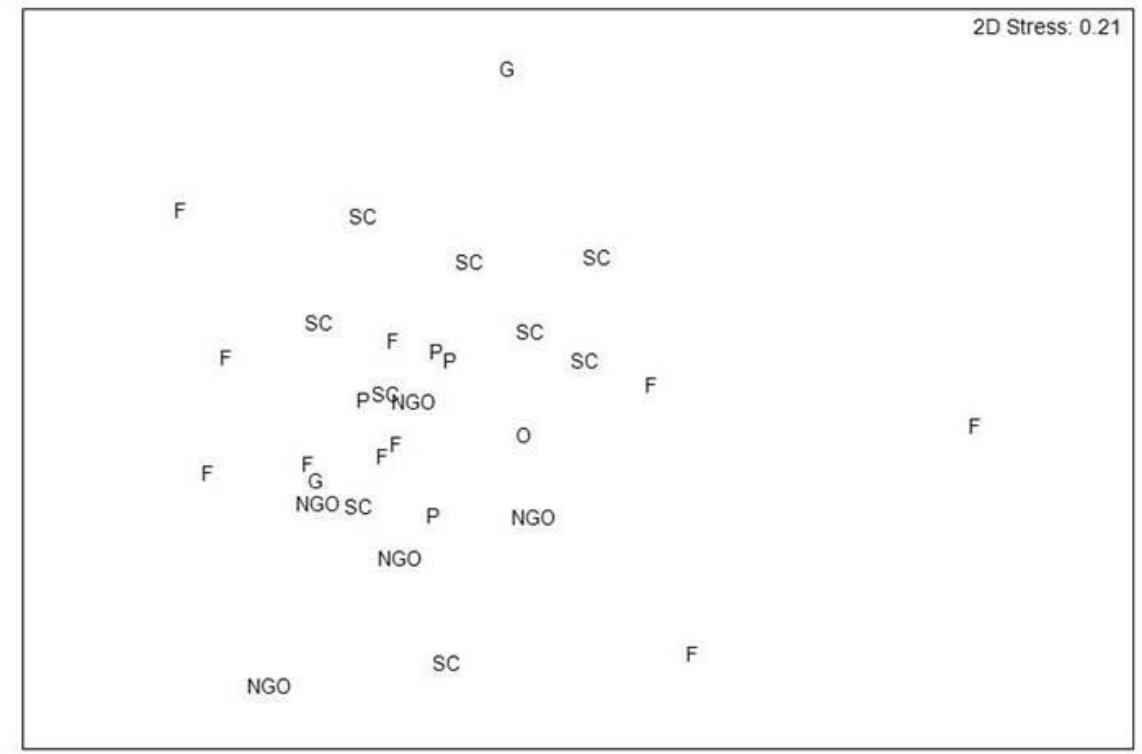

Figure 4: Non-metric multidimensional scale ordination of scores given to the top 25 knowledge-needs by the practitioners. $\mathrm{F}=$ Fishing industry, $\mathrm{G}=\mathrm{Government}, \mathrm{NGO}=$ Non-Governmental Organisation, $\mathrm{P}=\mathrm{Processor}$ and $\mathrm{SC}=$ research scientist. 
Annex 1: A list of participants in the knowledge-needs identification exercise showing their sector, their affiliation, nationality and their participation in the process. Note $*$ represents an inter-

governmental agency.

\begin{tabular}{|c|c|c|c|c|c|}
\hline Surname & & Sector & Group & Organisation & Countr \\
\hline Amaroso & R. & Scientist & Expert & University of Washington & US \\
\hline Andersen & M. & Fishing Industry & Stage 2 & Danish Fishermen Producer Organisation & Dk \\
\hline Balliet & $\mathrm{K}$. & NGO & Stage 2 & Sustainable Fisheries Partnership & US \\
\hline Barratt & E. & fishing industry & Stage 1 & Sanford Limited & NZ \\
\hline Bergstad & O.A. & Scientist & Stage 1 & Institute of Marine Research & No \\
\hline Bishop & S. & fishing industry & Stage 1 & Independent Fisheries Ltd & NZ \\
\hline Bostrom & J.L. & NGO & Stage $1 \& 2$ & Marine Stewardship Council & US \\
\hline Boyd & c. & Fishing industry & Stage 2 & Clearwater Seafoods & $\mathrm{Ca}$ \\
\hline Bruce & E.A. & Fishing Industry & Stage 2 & Friosur S.A. & $\mathrm{Cl}$ \\
\hline Burden & M. & Fishing industry & Stage 2 & Marine Conservation Alliance & US \\
\hline Carey & c. & fishing industry & Stage 1 & Independent Fisheries Ltd & NZ \\
\hline Clermont & J. & NGO & Stage 1 & New England Aquarium & US \\
\hline Collie & J.S. & Scientist & Expert \& Stage 2 & University of Rhode Island & US \\
\hline Delahunty & A. & Fishing industry & Stage 2 & National Federation of Fishermen's Organisations & UK \\
\hline Dixon & J. & Processor & Stage 1 & Pacific Andes Group & $\mathrm{Ch}$ \\
\hline Eayrs & S. & Scientist & Stage 2 & Gulf of Maine Research Institute & US \\
\hline Edwards & N. & Processor & Stage 1 & Icelandic Group Ltd. & UK \\
\hline Fujita & R. & NGO & Stage 1 & Environmental Defense Fund & US \\
\hline Gauvin & J. & Fishing Industry & Stage $1 \& 2$ & Alaska Seafood Cooperative & US \\
\hline Gleason & M. & NGO & Stage 1 & The Nature Conservancy & US \\
\hline Harris & B. & Scientist & Stage 2 & Alaska Pacific University - FAST Lab & US \\
\hline $\mathrm{He}$ & P. & Scientist & Stage 2 & University of Massachusetts Dartmouth & US \\
\hline Hiddink & J.G. & Scientist & Expert & Bangor University & UK \\
\hline Hilborn & R. & Scientist & Expert & University of Washington & US \\
\hline Hughes & K.M. & Scientist & Expert & Bangor University & UK \\
\hline Inostroza & M. & Processor & Stage 2 & EMDEPES & $\mathrm{Cl}$ \\
\hline Jennings & S. & Scientist & Expert & Centre for Environment, Fisheries and Aquaculture Science & UK \\
\hline Kaiser & M.J. & Scientist & Expert & Bangor University & UK \\
\hline Kenny & A. & Scientist & Stage 1 & Centre for Environment, Fisheries and Aquaculture Science & UK \\
\hline Kritzer & J. & NGO & Stage 2 & Environmental Defense Fund & US \\
\hline Kuntzsch & v. & Fishing Industry & Stage $1 \& 2$ & Sanford Limited & NZ \\
\hline Lasta & M. & Scientist & Stage 1 & Independent Scientist & $\operatorname{Ar}$ \\
\hline Lopez & I. & Fishing Industry & Stage 2 & CEPESCA & $\mathrm{Cl}$ \\
\hline Loveridge & C. & Government & Stage 1 & South Pacific Regional Fisheries Management Organisation & NZ \\
\hline Lynch & D. & Processor & Stage 2 & Gorton's Inc. & US \\
\hline Masters & J. & NGO & Stage 1 & Marine Conservation Society & UK \\
\hline Mazor & $\mathrm{T}$. & Scientist & Expert & CSIRO & $\mathrm{Au}$ \\
\hline McConnaughey & R. & Scientist & Expert & NOAA & US \\
\hline Moenne & M. & Fishing Industry & Stage 2 & Pacificblu & $\mathrm{Cl}$ \\
\hline Neat & F. & Scientist & Stage 1 & Marine Scotland Science & UK \\
\hline
\end{tabular}




\begin{tabular}{|c|c|c|c|c|}
\hline Nimick & A.M. & Scientist & Stage 2 & Alaska Pacific University \\
\hline Olsen & A. & Processor & Stage 1 & A. Espersen \\
\hline Parker & D. & Processor & Stage 1 & Young's Seafood \\
\hline Parma & A. & Scientist & Expert & Centro Nacional Patagonico \\
\hline Penney & C. & Processor & Stage 1 & Clearwater Seafoods \\
\hline Pierce & D. & Government & Stage 2 & Mass. Division of Marine Fisheries \\
\hline Pitcher & R. & Scientist & Expert \& Stage 1 & CSIRO \\
\hline Pol & M. & Scientist & Stage 2 & Division of Marine Fisheries, MASS State \\
\hline Richardson & E. & Fishing Industry & Stage 2 & Pollock Conservation Cooperative \\
\hline Rijnsdorp & A.D. & Scientist & Expert & Wageningen University \\
\hline Rilatt & S. & Processing & Stage 2 & A. Espersen \\
\hline Rodmell & D.P. & Fishing industry & Stage 2 & National Federation of Fishermen's Organisations \\
\hline Rose & c. & Scientist & Stage 2 & FishNext Research \\
\hline Sethi & S.A. & Scientist & Stage 2 & Alaska Pacific University - FAST Lab \\
\hline Short & $\mathrm{K}$. & NGO & Stage 1 & WWF \\
\hline Sutherland & W.J. & Scientist & Expert & Cambridge University, U.K. \\
\hline Suuronen & P. & Government* & Expert \& Stage 2 & FAO, Fisheries and Aquaculture Department \\
\hline Taylor & E. & NGO & Stage 2 & New England Aquarium \\
\hline Wallace & S. & NGO & Stage 1 & The David Suzuki Foundation \\
\hline Webb & L. & Processor & Stage 2 & Gorton's Inc. \\
\hline Wickham & L. & Fishing Industry & Stage 1 & Fishing business \\
\hline Wilding & S.R. & NGO & Stage 2 & Monterey Bay Aquarium \\
\hline Wilson & A. & Government & Stage 1 & Department for Environment, Food and Rural Affairs, U.K. \\
\hline Winger & P. & Scientist & Stage 2 & Memorial University \\
\hline
\end{tabular}


Annex 2: The full list of 108 knowledge needs submitted in stage 1 of the process, showing the question number that relates to Table 3 and their assigned category (for definitions see Table 2).

Number

1

4 and habitats (i.e., what kind of information about habitats and about gear types do we need to know)?

What outcome reference points and indicators of habitat status are possible given today's knowledge level? What are the most significant issues to consider in relation to qualifying or quantifying impact extremes?

How do trawl designs and operational practices influence impact characteristics and patterns?

Under what conditions can benthopelagic trawling replace bottom-contact trawling for demersal target species?

How can trawling on/above summits of seamounts and on steep slopes be conducted without significant adverse impacts on sessile benthos?

How can instrumentation for real-time monitoring of trawling improve targeting and enhance impact prevention?

Lasting impact of trawling on 'vulnerable marine ecosystems' (sensu FAO Guidelines) occurred and may still happen. What are the more efficient mitigation measures? (e.g. area closures, technical measures, overall effort reductions, etc.)

What sort of mitigation measures are in line with best practices? What examples are available for each measure?

What sort of area (e.g., regional, bioregional) should be considered when defining habitat status reference levels in quantitative terms?

What sort of global benchmarks, if any, exist for determining an acceptable habitat impact and for determining irreversible harm?

How best can the status and outcome of benthic impacts be measured? What best practices exist?

What types of attributes (or gear characteristics) can be used to provide a consistent and systemic way of ranking or measuring relative impact on habitat across different gear types? How can such attributes be assessed in a uniform and consistent manner?

At what "intensity" (e.g., amount of fishing effort) are fisheries employing pelagic gear that occasionally contacts the seafloor (e.g., pelagic trawls) as impactful as full-bottom contact fisheries? Should these fisheries be regulated in the same way as bottom trawl fisheries?

What are the habitat-related variables (e.g., biota, substrate type, physical characteristics, current flow, etc) that are correlated with resilience to disturbance from trawling in benthic habitats? 
What part of the gear (e.g., doors, sweep/bridle area, footrope) plays the largest role in disturbing particular habitat types? Does the part of the gear causing the most disturbance change with different habitat characteristics (e.g., cobble, mud/sand, high relief, etc)?

What aspects of towing a mobile bottom-tending gear (e.g., tow length and time, tow path, speed, etc.) causes the most disturbance to particular habitat types? Does the relative impact differ by habitat type?

How can fish behavior (e.g., aggregating, flight response) be better used to increase efficiency and/or reduce bottom time for bottom-tending gear?

What types of post-trawl CPUE effects would need to be exhibited in an area to dissuade further trawling for a period of time (i.e., a disincentive for fishing) in both the short-term and longterm. In what ways could a fishery benefit from a short-term avoidance of a typically productive area?

How are units of fish productivity quantitatively related to units of trawl impact?

How much does trawling cost per unit value of fish caught, and how does this compare to the cost/value of other kinds of gear/practices?

How much greenhouse gas emissions are associated with trawling and can carbon credits based on estimated reduced trawl hours (and associated emissions) resulting from policy change (e.g., a buyout or shift to ITQs) be used to finance the policy change and/or transition to other types of fishing?

What are the benefits of trawling and how can they be realized while minimizing the economic and environmental costs of trawling?

What are the "best practices" for trawling in order to minimize impacts on other fisheries, habitat, biodiversity, and ecosystem services?

What is the magnitude of bycatch and discard impacts associated with trawling and how can they be reduced?

What does the trawling system map look like and where are the highest leverage interventions that would improve social, environmental, and economic outcomes?

We have harvested upwards of 1.5 million tonnes of groundfish annually in the Bering Sea with bottom contact trawls for 40 plus years and the effects of trawling literature would suggest that stocks would be reduced, species diversity would have changed but trawl survey does not show this. Could effects on habitat be so lagged that we have not seen them yet or are we below some threshold where trawling is not intense enough over the area to cause noticeable effects? What gives? 
A large percentage of the Bering Sea sand/mud shelf of $<200$ meters depth is closed bottom trawling (some to Pollock trawling as well); this no doubt has increased effects on the area left open by concentrating effort and intensity but is there net benefit to stocks and habitat?

Are there any studies that show how management of trawl effects on the seafloor have demonstrably increased productivity of managed groundfish and crab species in temperate ecosystems?

If there are studies as described in Q30 above, how have the researchers separated the differences in fish harvest rates and climate/environmental changes over time from effects on habitat?

To what extent does the haphazard spatial and temporal pattern of trawling, and variable impacts within trawl tracks, create a pattern of effective refuges within fished areas and how does this vary by fishery and fishing intensity? Can these be studied in lieu of closing more areas to trawling?

Does the presence or frequency of seafloor invertebrates in samples from trawl catches (survey or in observer data) provide a useful measure of their distribution on the seafloor? How might observer basket sampling methods and coverage issues affect this utility?

How close does trawl gear have to be to the seafloor to effectively capture benthic fish and how high off the seafloor does it have to be to avoid most benthic impacts? Is there a clearance range that achieves both?

Are there non-contact stimuli that could herd fish and move them into a net that could replace conventional trawl components?

From a fish habitat perspective, are small patches of structure here and there on an otherwise featureless/flat seafloor potentially more important than free-standing deep sea corals and sponges anchored to high relief rocky outcrops and rock ledges?

Sweep modifications required for Bering Sea flatfish trawls have been shown to reduce seafloor contact by approx. $90 \%$ and decrease effects on typical epibenthic invertebrates, but the elevated trawl sweeps increase penetration of the seafloor where the bobbins make contact (spaced every 30 meters). Is this on balance a benefit to preserving the productivity of the habitat?

How does trawling affect the micro-topographic complexity and diversity of the seafloor and invertebrate communities that inhabit it and how do recovery patterns differ between different habitat types (eg. Various types of hard and soft bottom substrates)?

How does trawling affect macro-faunal (both sessile and mobile) invertebrate communities and how resilient are these invertebrate communities to varying levels or intensities of trawl effort?

How does the impact of trawling and recovery times post-trawling differ by depth (say along the 
What impact does trawling have on the density and diversity of species typically discarded (eg. Skates, rays, non-marketable finfish, etc)?

One of the more common observed impacts of trawling is the grooves in the seafloor caused by trawl door scour. What effect do those trawl door scour marks play in shaping benthic community structure?

What role, if any, do these sessile and mobile invertebrate communities play in terms of providing habitat/shelter for the recruitment juvenile and larval fishes?

What are the relative benefits of spatial management to constrain the trawl fleet footprint versus trawl effort controls or both? (ie. Should a lower intensity of trawl effort be spread out over a larger area of trawl grounds or should trawl effort be concentrated into a smaller footprint, but perhaps a higher intensity of trawling per unit area?

What are the rates of recovery/ re-growth for different benthic species and habitats to various fishing gears and components (dredge, trawl doors, ground gear etc.)?

Are there a sufficient number and size of unfished patches of habitat type to enable recolonisation of an impacted habitat?

What proportion and arrangement of each habitat type needs to be protected by closures to ensure viable populations of benthic organisms and enable recovery of impacted areas?

What is the benthic species mortality rate per trawl by substrate type?

What is the spatial extent and level of effort of bottom fishing by smaller (inshore) vessels not equipped with VMS?

How could trawling help to improve biodiversity?

What is the sustainable level of biodiversity in specific habitats?

What level of biodiversity do we wish to attempt to maintain?

Large sessile megafauna (eg. sponges, gorgonians, soft/hard corals, bryozoans — individually, or as aggregations) that form biogenic structured habitat are thought to be highly vulnerable to trawl impacts, but what are the actual impact rates, recovery rates, distributions, and overlap with trawling of these fauna.

What is the relative importance in the ecosystem of large sessile ("charismatic") megafauna and what important processes may be affected if these habitats are substantially damaged by trawling

In the absence of specific survey data, to what extent can the distributions of species and habitats vulnerable to trawling be predicted with sufficient reliability to enable successful assessments 
How can we enhance the knowledge obtained from past comparisons between trawled and untrawled areas (lacking data on 'before' status and on the 'intensity' of effort), by making use of good environmental predictors and modern reconstructions of trawl effort distribution, to extract more specific parameters for impact rates and magnitudes of (trawl-induced) change

What have been the observed benefits of spatial management versus effort management in terms of reducing environmental impact / improving sustainability.

Alternatively, under what circumstances does spatial management lead to improvements and under what circumstances does effort management lead to improvements

What are the impact \& recovery implications of aggregated effort, at multiple scales, and how stable are patterns of aggregation across space and time, at different scales

61 How do different types of bottom fishing gear differ in their interactions with the seabed

How do different types of seabed habitats differ in their susceptibility to impacts from towed gear and their ability to recover after such impacts?

How does disturbance by towed gear differ from natural perturbations experienced by seabed habitats?

To what extent are the impacts of towed fishing gear mediated by variation in habitat susceptibility, in species recovery rates and in spatial overlaps between distribution of fishing effort intensity and the distribution of habitats?

To what extent is the identification of best practice management measures contingent upon differences in management objectives and the values that are sought to be maintained?

Are benthic trawl impacts generally greater upon substrates that have physically complex and diverse communities, compared to simple/bare substrates? Is this regardless of whether the fishing effort is 'patchy' in time or space?

How can BRD design and deployment reduce benthic impacts, by ensuring a high proportion of the benthic fauna and flora is expelled from nets close to where it enters the net. That is, is highest mortality associated with being brought to the surface and being discarded, and is this mortality avoided by BRDs. Does this have more relevance to mobile fauna (i.e., fish and invertebrates) than the sessiles. Can net design features reduce 'towed bottom fishing gear' impacts on seabed

What is the relative biomass removed by trawling/contributed by discarding compared with the natural amount of total biomass/detritus arriving at the seabed. How might bottom fishing gears 
To what extent would plumes from benthic fishing gears alter light penetration and photosynthetic processes, which may affect the biochemical cycling, at levels significantly greater than those associated with natural events/processes.

How to develop and implement management strategies that could be considered informed in relation to target species as well as other at risk aspects (e.g. ecological) of the fishery

What are the risks of trawling to various components of the ecosystem. What research can give some confidence around understanding of the risks and nature of impacts on seabed communities from trawl fishing

What are the risks of trawling to various components of the ecosystem. How can these risks be assessed and managed in largely unstudied areas of seabed, often in deepwater areas

What are the perceptions of the impacts trawling is having, and to what extent can any additional

Do impacted communities have predictable trajectories to original 'successional' states following trawl disturbance, or remain in altered states of structure and functional process? How might this vary between benthic ecosystems? Do systems based on biogenic habitats represent the least resilient? Can resilience be built into management planning — is this key to long term sustainable use of benthic habitats for trawling, especially when climate impacts are overlaid.

Restricting trawling within a footprint is implemented in a variety of different structured fishery seascapes; is this a tractable and effective method for management. Where trawling occurs, and where trawl impacts are expected to be long-lived, what options are there for estimating the rate at which never-trawled habitats are 'opened up' and the regional scale of impact gradually increases? How can this be measured and quantified given the scale of the habitat and activities compared with the resolution and uncertainty of the effort data.

What is the evidence for the importance of physical structures as refuges, and for other mechanisms resulting in flow-on effects to ecosystems. For example, do benthic megafauna provide substrata for fish eggs (seapens-rockfish), structures for associate fauna (echinodermscorals), and physical substrata providing shelters for early life history stages of commercial species. Is there evidence for other mechanisms - e.g. enhanced prey densities, water flow refuges, sediment re-suspension, disturbance providing advantage to colonisation by weedy species. Is this knowledge necessary to understand the impacts and articulate the case for 
Can the extraction of feature-aggregating species (e.g. Orange Roughy on seamounts) be ecologically sustainable when side-by-side with vulnerable benthic communities? What is the potential for partly impacted features to contribute to broader spatial scale recovery, i.e. provide propagules for local to regional scale dispersal? Is this information essential to manage and understand the impacts on VMEs and high seas areas

To what extent is understanding and management assisted by understanding what/where/how much habitats are untrawlable at a variety of scales. Should such areas be considered (along with closures) in making environmental assessments of trawling. To what extent do better maps of habitat, improved navigational technology, and changing fishing practices (eg. increased risk taking when market prices are high) contribute to determining trawlable and untrawlable bottom.

To what extent can landed invertebrate bycatch represent the damage to seabed fauna. Would this underestimate the damage to fauna because many are not retained well in nets. Can such methods quantify the direct impacts in different community types and help understand the importance of fishing intensity and the cumulative effects across gears.

Can faunal categories potentially emphasise taxonomic relationships, size categories, ecological function, and vulnerability to trawling. Are standardised descriptors of 'habitat fauna' needed

Do standards need to be developed for improving incorporation of trawl impacts into risk assessment frameworks, with focus on separating impact from risk, increasing quantification, and being explicit about the spatial and temporal scales being considered.

Once an area has had a history of being trawled (inside the trawl footprint as known fishing grounds), what ongoing ecosystem damage is occurring by continuing to trawl in this area? Does this include changes in composition. What is the best way to measure trawling over a certain area (number of tows, hours, etc)

What level of damage occurs from using different net and ground gear designs for each habitat type (as classified under the habitat and communities ERA framework)? Will this need to look at different combinations of gear (including Danish seine, demersal trawl and midwater trawl).

What is the recovery time of the different habitat types (as categorised under the habitat and communities ERA framework) for different levels of effort, for each fishing method?

Once trawling has taken place what is the recovery process? Is it succession based; does it ever 
What are the effects of trawling on species richness and diversity of the different habitat types (as categorised under the habitat and communities ERA framework)

How large and how many closure areas are needed to provide adequate protection for a type of community and/or habitat?

Specifically, what are the impacts of fish trawling on the benthos, fish communities and commercial fish stocks.

Is physical damage to habitats caused by trawling irreversible. What is required to test for

Do series of closed areas and areas with different levels of fishing effort represent a 'natural' experiment.

What are the post-trawling recovery levels of habitats and benthic ecosystems in areas closed to trawling, and what are the responses of dependent fish populations and communities that rely upon them. Are there interactions effects (or benefits) of areas closed to trawling in/adjacent to fished area (does it affect recruitment levels etc).

94 What and where are the various seabed types

What effect does bottom trawling have on the various seabed types.

96 What specific effect does twin rigging have on the various seabed types.

97 How important are the various seabed types to fish life through the various stages of fish life.

98 What effect does seabed disturbance by trawling have on the sustainability of fishstocks.

99 What natural events will change seabed environments

What is the current trawl footprint and is this likely to change-this should incorporate closed areas,areas too deep to trawl,areas too rough to trawl,etc

What types of bottom trawl caught species live near but off the bottom and could be caught off the bottom completely with midwater trawls but currently there is no incentive to do so?

101 Example, several rockfish species, west coast Canada.

What gear configurations exist to mitigate impacts and how much net reduction in impact is

102 gained? Example, off bottom doors

What are the potential or measured impacts of resuspending sediments in areas of low oxygen concentration (example, west coast North America oxygen minimum zones)?

What changes are made to a specific type of bottom i.e. coral, mud gravel etc. by repeated

105 bottom trawling?

106 Are these changes [to habitat by repeated trawling] reversible? If so how?

107 If trawl gear is towed a fraction of a meter off the bottom is there any damage to the habitat? 
